\title{
Sampling and Analysis Plan for Old Solvent Tanks S1-S22 to Address Waste Acceptance Criteria
}

by

P. E. Filpus-Luyckx

Westinghouse Savannah River Company

Savannah River Site

Aikén, South Carolina 29808

This paper was prepared in connection with work done under the above contract number with the U.S.

Department of Energy. By acceptance of this paper, the publisher and/or recipient acknowledges the U.S. Government's right to retain a nonexclusive, royalty-free license in and to any copyright covering this paper, along with the right to reproduce and to authorize others to reproduce all or part of the copyrighted paper. 
Sampling and Analysis Plan for Old Solvent Tanks S1-S22

to Address Waste Acceptance Criteria (U)

\section{P. E. Filpus-Luyckx}

Unclassified

Does Not Contain Unclassified Controlled Nuclear Information (UCNI)

OCTOBER 2, 1997

Westinghouse Savannah River Company

Savannah River Site

Aiken, SC 29808

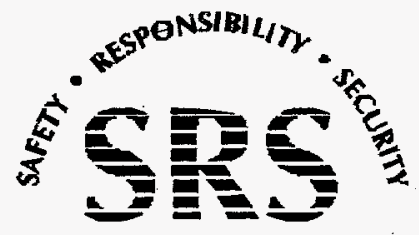




\section{DISCLAIMER}

This report was prepared as an account of work sponsored by an agency of the United States Government. Neither the United States Government nor any agency thereof, nor any of their employees, makes any warranty, express or implied, or assumes any legal liability or responsibility for the accuracy, completeness, or usefulness of any information, apparatus, product, or process disclosed, or represents that its use would not infringe privately owned rights. Reference herein to any specific commercial product, process, or service by trade name, trademark, manufacturer, or otherwise does not necessarily constitute or imply its endorsement, recommendation, or favoring by the United States Government or any agency thereof. The views and opinions of authors expressed herein do not necessarily state or reflect those of the United States Government or any agency thereof.

This report has been reproduced directly from the best available copy.

Available to DOE and DOE contractors from the Office of Scientific and Technical Information, P.O. Box 62, Oak Ridge, TN 37831; prices available from (615) 576-8401.

Available to the public from the National Technical Information Service, U.S. Department of Commerce; 5285 Port Royal Road, Springfield, VA 22161. 


\section{DISCLAIMER}

Portions of this document may be illegible electronic image products. Images are produced from the best available original document. 


\section{TABLE OF CONTENTS}

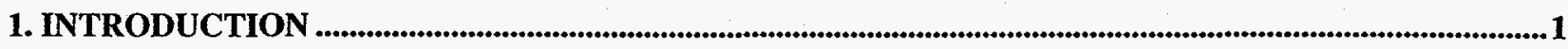

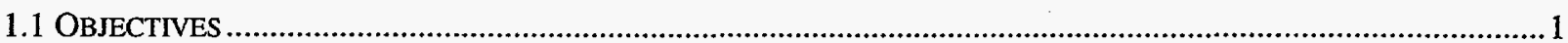

1.2 SCOPE

2. BACKGROUND INFORMATION

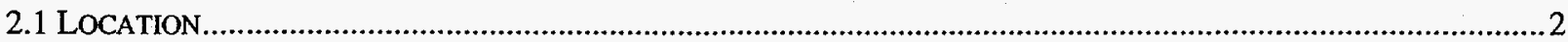

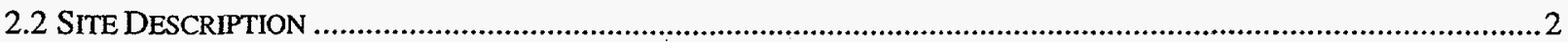

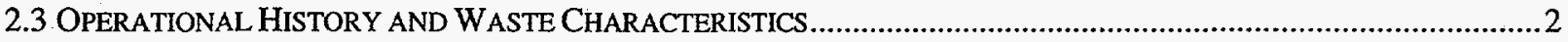

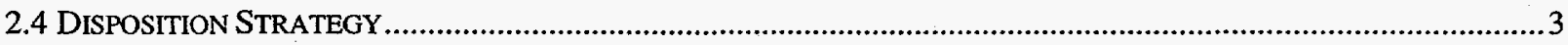

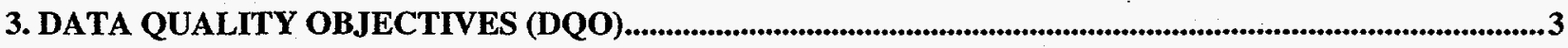

3.1 Old SOlvent TANKS S1-S22 IN THE Old Radioactive WaSte BuRIal Ground 643-E DQO

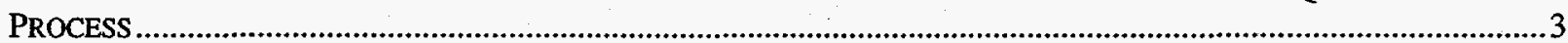

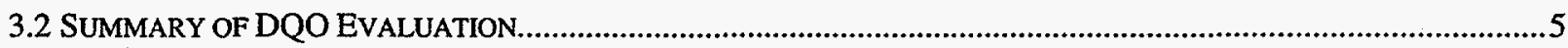

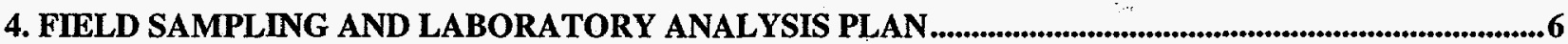

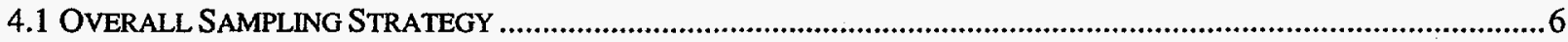

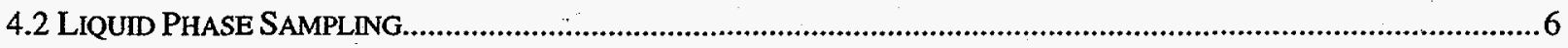

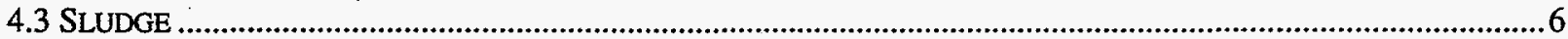

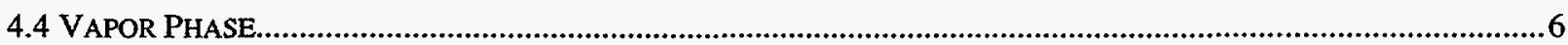

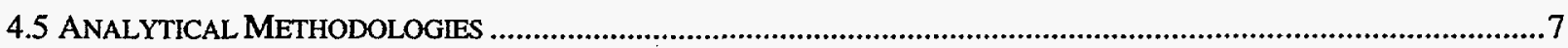

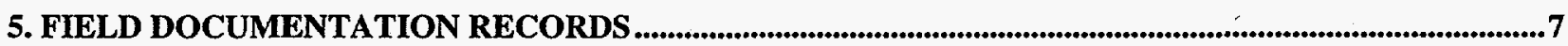

5.1 FIELD SAMPLE CHAIN-OF-CUSTODY

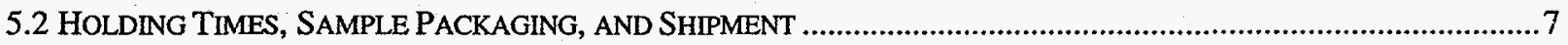

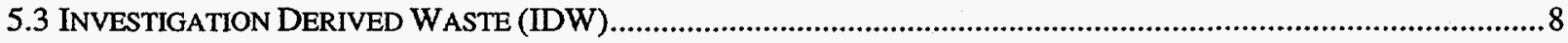

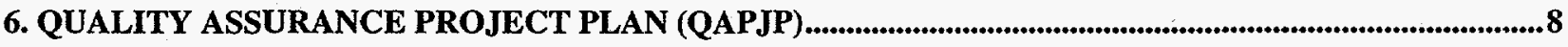

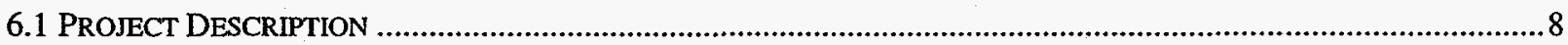

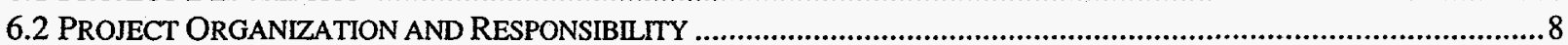

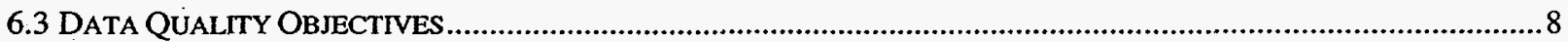

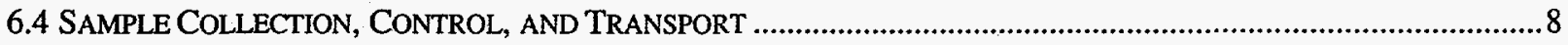

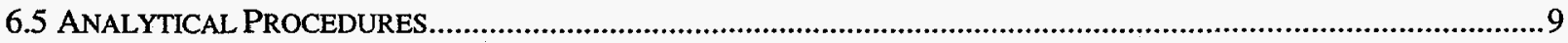

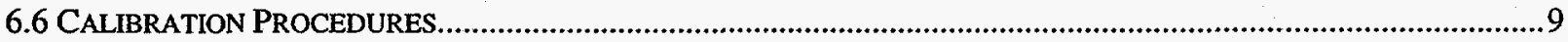

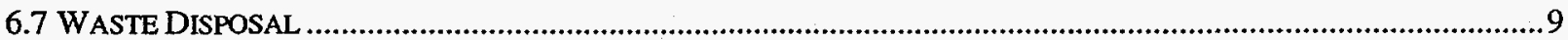

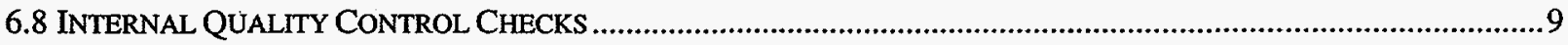

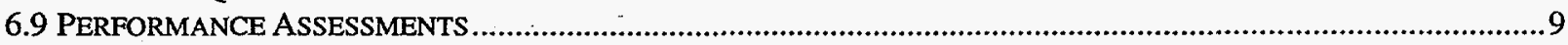

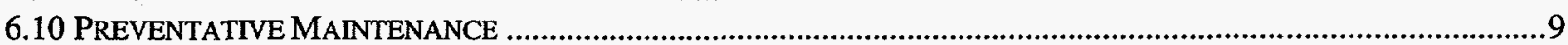

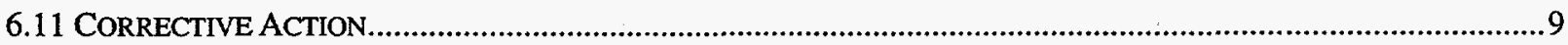

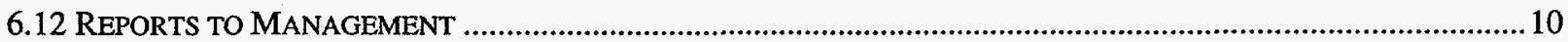

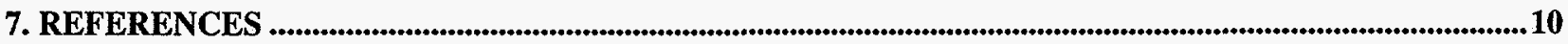

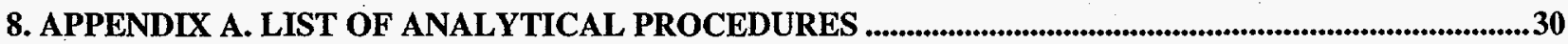




\section{LIST OF FIGURES}

1 Location of the ORWBG in relation to other E Areas 11

2 Location of Tanks S1-22 in Relation to the ORWBG 12

3 Relative locations of Tanks S1-22 13

$4 \quad$ Material Disposition Strategy 14

5 Field Chain-of-Custody Form 15

\section{LIST OF TABLES}

1 Analytical Constituents, Parameters, and Detection Limits 16

2 Analytical Methods and Hold Times 26 


\section{LIST OF ACRONYMS}

$\begin{array}{ll}\text { AAS } & \text { Atomic Absorption Spectrophotometry } \\ \text { ADS } & \text { Analytical Development Section } \\ \text { CIF } & \text { Consolidated Incineration Facility } \\ \text { COC } & \text { Chain-of-Custody } \\ \text { CVAA } & \text { Cold Vapor Atomic Absorption } \\ \text { DQO } & \text { Data Quality Objective } \\ \text { ERD } & \text { Environmental Restoration Department } \\ \text { EPA } & \text { United States Environmental Protection Agency } \\ \text { GC } & \text { Gas Chromatography } \\ \text { GC/MS } & \text { Gas Chromatography/Mass Spectrometry } \\ \text { HLWD } & \text { High Level Waste Division } \\ \text { IC } & \text { Ion Chromatography } \\ \text { ICP-ES } & \text { Inductively-Coupled Plasma-Emission Spectroscopy } \\ \text { ICP-MS } & \text { Inductively-Coupled Plasma-Mass Spectrometry } \\ \text { IDW } & \text { Investigation-Derived Waste } \\ \text { LEPS } & \text { Low Energy Photon Spectroscopy } \\ \text { LSC } & \text { Liquid Scintillation Counting } \\ \text { MWSF } & \text { Mixed Waste Storage Facilities } \\ \text { ORWBG } & \text { Old Radioactive Waste Burial Ground } \\ \text { PHA } & \text { Pulse Height Analysis } \\ \text { QA } & \text { Quality Assurance } \\ \text { QAPjP } & \text { Quality Assurance Project Plan } \\ \text { QC } & \text { Quality Control } \\ \text { SAP } & \text { Sampling and Analysis Plan } \\ \text { SRS } & \text { Savannah River Site } \\ \text { SRTC } & \text { Savannah River Technology Center } \\ \text { SST } & \text { Solvent Storage Tank Facility } \\ \text { SWD } & \text { Solid Waste Division } \\ \text { TCLP } & \text { Toxic Characteristic Leaching Procedure } \\ \text { TOC } & \text { Total Organic Carbon } \\ \text { TRU } & \text { Transuranic } \\ \text { WAC } & \text { Waste Acceptance Criteria } \\ \text { WSRC } & \text { Westinghouse Savannah River Company } \\ \text { XRD } & \text { X-ray Diffraction } \\ \text { XRS } & \text { X-ray Spectroscopy } \\ & \\ \text { SW } & \\ \text { SW } & \end{array}$




\section{INTRODUCTION}

The Environmental Restoration Department (ERD) assumed custody of the Old Solvent Tanks (Tanks S1-S22) in the Old Radioactive Waste Burial Ground (ORWBG, 643-E) from Waste Management in January 1991. The purpose of this Sampling and Analysis Plan (SAP) is to collect and analyze samples of the sludge solids, organic and aqueous phases to determine the level of radioactivity, the isotopic constituents, the specific gravity, and other physical parameters. These data must be obtained to evaluate the process safety of remediating the tanks, to determine the disposal path for the material in the tanks, and to determine the most viable closure technology for the tanks.

\subsection{Objectives}

Project objectives are:

- To update and supplement existing compositional information regarding the vapor phase, liquid phase(s), and solid phase(s) in each tank.

- To provide sufficient compositional information to develop the safety envelope for waste removal and tank closure in a way that will not unnecessarily constrain operations.

- To quantify the necessary constituents and physical parameters in the solvent and aqueous phases to meet the Waste Acceptance Criteria (WAC) at the Solvent Storage Facility $^{1}$ (SST) operated by Solid Waste Division (SWD) and to meet the WAC for incineration at the Consolidated Incineration Facility ${ }^{2}$ (CIF).

- To quantify the necessary constituents and physical parameters in the sludge phase for acceptance at the 241-F/H Tank Farms ${ }^{3}$ operated by High Level Waste Division (HLWD).

- To quantify the necessary constituents and physical parameters in the solvent, aqueous and sludge phases to meet the Waste Acceptance Criteria (WAC) at the Mixed Waste Storage Facilities ${ }^{4}$ (MWSF) operated by SWD.

\subsection{Scope}

The scope of this SAP includes: collecting samples of the liquid phase(s), and Solid phase(s) (sludge) from specific tanks; analyzing the samples to determine compliance with the Waste Acceptance Criteria of potential accepting SRS Waste Treatment Facilities; collecting samples of the vapor phase from specific tanks; and analyzing the samples to provide the information required for environmental, safety and health considerations. ERD will develop criteria specifying which tanks will be sampled. This criteria will be based on actual tank conditions observed during previous video surveys. 


\section{BACKGROUND INFORMATION}

\subsection{Location}

The ORWBG (Building Number 643-E) comprises approximately 76 acres located in the north-central portion of SRS, about five miles southeast of A-Area on the north side of Road $\mathrm{E}$ between F- and $\mathrm{H}$-Areas (Separations). The ORWBG was a trench disposal area which received radioactive waste from 1952 until 1972. A map showing the ORWBG in relation to the locations of the major E-Area facilities is included in Figure 1.

\subsection{Site Description}

The 22 Old Solvent Tanks are located in a "T"-shaped block near the center of the ORWBG about 400 feet northeast of the Burial Ground Administration Building 724-7E and 500 feet north of Road E. A map showing the location of the Old Solvent Tanks S1-S22 in relation to the ORWBG is included in Figure 2. The relative location of each tank is shown in Figure 3.

\subsection{Operational History and Waste Characteristics}

The Old Solvent Tanks S1-S22 were single-wall steel tanks installed between 1955, and 1968 to receive spent PUREX solvent from Separations in F- and $\mathrm{H}$-Areas. The tanks are all cylindrical, single-wall carbon steel tanks buried with the long axis horizontal. Each tank was installed with an approximate inclination of six inches.

In the PUREX process, targets and spent fuel rods were processed in Separations to recover activation products and to recover residual plutonium and uranium for recycling. The targets and rods were clipped into small pieces and placed in the nitric acid dissolver solution to dissolve the plutonium and uranium. The PUREX solvent, which consisted of tri-n-butyl phosphate dissolved in kerosene, was used to extract plutonium and uranium from the dissolver solution. Plutonium and uranium were recovered from the solvent and the solvent was recycled. After a number of cycles, the solvent became degraded and was neutralized with caustic compounds and stored in Tanks S1-S22 for aging. During the aging period, generally about six months, most of the short-lived, high-gamma fission products decayed and the heavy alpha emitters settled out of the solvent. The solvent separated into three phases: organic, aqueous, and sludge solids, consisting of alpha emitters in hydroxides and dibutyl phosphate complexes.

After aging, the sludge solids accumulated in the bottoms of Tanks S1-S22. The organic phase was drawn out of the tanks and burned in shallow pans placed in trenches in the Old Radioactive Waste Burial Ground. Approximately 382,750 gallons of spent solvent were burned between 1956 and 1972 . 
Tanks S1-S18 were pumped out to "unpumpable heel" in the solvent relocation program between March 1977 and May 1978. The solvent was placed in Tanks S19-S22. Tanks S19-S22 were pumped out and the solvent was transferred to Tanks S23-S30 between November 1980 and January 1981. No additional waste was placed in Tanks S1-S22 after January 1981. The total volumes of the material remaining in Tanks S1-S22 is $\sim 8000$ gallons of liquid and up to $1250 \mathrm{Kg}$ solids. These values are being confirmed by remote camera surveillance.

Thus, one of the objectives of this SAP is to yield analytical results which can update and supplement existing compositional information regarding the vapor phase, liquid phase(s), and solid phase in each tank.

\subsection{Disposition Strategy}

The material disposition strategy that this Sampling and Analysis Plan supports is shown in Figure 4

\section{DATA QUALITY OBJECTIVES (DQO)}

According to the United States Environmental Protection Agency (EPA), "The DQO Process was developed to help EPA personnel collect data that are important to decision making". The process allows decision makers to define their data requirements and acceptable levels of decision errors while in the planning stage (before data are collected). Application of the DQO Process will result in the collection of data that yield results of appropriate quality for "defensible decision making". The DQO process is designed to ensure that the appropriate type, quality and quantity of environmental data match the intended applications.

The Data Quality Objectives (DQOs) for this project represent the level of analysis needed to quantify the contents adequately to allow evaluation of the process safety envelope and to evaluate transfer to SWD and/or HLW facilities.

\subsection{Old Solvent Tanks S1-S22 in the Old Radioactive Waste Burial Ground 643-E DQO Process}

Old Solvent Tanks S1-S22 in the Old Radioactive Waste Burial Ground 643-E are radioactively contaminated sites with the potential for commingled radiological and chemical contamination. The intended application of the Sampling and Analysis Plan is to collect datato support transfer to SWD and HLW Waste Treatment facilities. Meeting the WACs of these Waste Treatment facilities requires both radiological and chemical characterization. 


\subsection{Problem}

Determine the appropriate sampling scheme necessary to characterize solvent and sludge phases of selected tanks to identify disposal options for the solvent and sludge.

\subsubsection{Key Decisions}

- Determine the composition of the vapor phase to provide design data and support environmental, safety and health considerations for the disposition of material in the tanks.

- Determine the chemical and radiological constituents in each liquid phase to determine compliance with the SST WAC, the CIF WAC, the TRU Pad WAC ${ }^{5}$ and/or the MWSF WAC.

- Determine the chemical and nuclide constituents in the sludge to evaluate the criticality safety envelope for waste removal and tank closure activities.

- Determine the chemical and radiological constituents in the sludge to determine compliance with the F/H Tank Farms WAC, the TRU Pad WAC and/or the MWSF WAC.

\subsubsection{Identify the Inputs to the Decisions}

- Definitive analytical data will be used to determine chemical and radiological constituents in the vapor phase.

- Definitive analytical data will be used to determine the chemical and radiological constituents in the liquid phase(s).

- Definitive analytical data will be used to determine the chemical and radiological constituents in the sludge phase.

\subsubsection{Define the Boundaries of the Study}

The primary goals of this sampling plan are to quantify the nature of the material within Tanks $S 1$ through $S 22$ to support evaluation of the safety envelope and to compare to the SST, CIF, MWSF, F/H Tank Farms, TRU Pad and the MWSF WACs.

\subsubsection{Decision Rules}

- If the tank has < 50 gallons of solid phase, THEN no solid samples will be taken.

- IF the as-received sample has both a solid AND liquid phase(s), THEN the sample will be filtered by the Analytical Development Section (ADS) of the Savannah River Technology Center (SRTC) to segregate the solid sludge from the liquid. 
- IF the liquid (or filtrate) shows both an organic AND an aqueous phase, THEN the two phases will be separated by ADS and analyzed separately.

- IF the solid material shows more than one phase, THEN the phases will be separated by ADS to the extent practicable and analyzed separately.

- IF the liquid phase(s) meet the SST and CIF WAC, THEN the liquids can be transferred to the SST facility. ELSE, the composition of the liquid phase(s) will be compared to the TRU limit.

- IF the liquid phase(s) exceed the $100 \mathrm{nCi}$ TRU/g AND the TRU Pad WAC is met, THEN the liquids can be transferred to the TRU Pad. ELSE, the composition of the liquid phase(s) will be compared to the MWSF WAC.

- IF the liquid phase(s) meet the MWSF WAC, THEN the liquids can be transferred to the MWSF. ELSE, stabilization in place will be evaluated.

- IF the solid phase meets the F/H Tank Farm WAC, THEN the solids can be transferred to the F/H Tank Farm. ELSE, the composition of the solid phase will be compared to the TRU limit.

- IF the solid phase exceed the $100 \mathrm{nCi}$ TRU/g AND the TRU Pad WAC is met, THEN the solids can be transferred to the TRU Pad. ELSE, the composition of solid phase will be compared to the MWSF WAC.

- IF the solid phase meets the MWSF WAC, THEN the solids can be transferred to the MWSF. ELSE, stabilization in place will be evaluated.

- IF any WAC is not met, THEN the compositional data derived from this SAP will be used to support a deviation request or evaluation for in place stabilization of the materials.

\subsubsection{Tolerance for Uncertainty}

The establishment of sampling protocol and use of definitive analyses will minimize potential errors introduced during field operations.

Given the nature, history, and inaccessibility of the material in the tanks, there exists the potential for the samples to be non-representative due to non-homogeneity of the tank contents. Any such additional uncertainties will likely cause the criticality safety controls to be more restrictive than otherwise, due to the conservative nature of such calculations.

\subsection{Summary of DQO Evaluation}

The solvent and sludge phases for each tank will need to be analyzed for all chemical and radiological constituents required by the respective WACs and to support evaluation of the safety envelope. 


\section{FIELD SAMPLING AND LABORATORY ANALYSIS PLAN}

\subsection{Overall Sampling Strategy}

The overall field sampling strategy will, to the greatest extent possible, obtain samples from the tanks that will be representative of all phases present in the tank.

\subsection{Liquid Phase Sampling}

Organic phase and aqueous phase samples will be collected using a pumping system designed and fabricated by the Engineered Equipment \& Systems Section, SRTC. The sample will be obtained at the lowest end of the tank, directly below the tank riser pipe. Certain tanks with large quantities of liquids will be sampled at both ends of the tank. The sampling devices must limit sample volume to avoid risks of criticality when working with materials of unknown composition. Specific volume limits will be documented in a Nuclear Criticality Safety Evaluation to be provided before sampling begins. The entire sample will be sent to ADS. If the as-received sample has both a solid and liquid phase(s), then the sample will be filtered by ADS to segregate the solid sludge from the liquid. If the liquid (or filtrate) shows both an organic and an aqueous phase, the two phases will be separated by ADS and analyzed separately for the constituents and physical parameters shown in Table 1. The selected parameters are those specified in the SST, CIF and MWSF WACs.

\subsection{Sludge}

Sludge phase samples will be collected using the same pumping system as that used to collect the liquid samples. The sludge sample will be obtained at the lowest end of the tank, directly below the tank riser pipe. Certain tanks with large quantities of sludge will be sampled at both ends of the tank. Separate sludge samples will be taken from tanks with large quantities of both liquid and sludge. The sampling devices must limit sample volume to avoid risks of criticality when working with materials of unknown composition. Specific volume limits will be documented in a Nuclear Criticality Safety Evaluation to be provided before sampling begins. The entire sample will be sent to ADS. If the as-received sample has both a solid and liquid phase(s), then the sample will be filtered by ADS to segregate the solid sludge from the liquid. The filter residue will be analyzed for the constituents and physical parameters shown in Table 1 . The selected parameters are those specified in the F/H Tank Farm and the MWSF WACs.

\subsection{Vapor Phase}

Hydrogen samples will be collected by pumping $1 / 2$ liter of tank air into a Tedlar ${ }^{\mathbb{*} *}$. Three hydrogen samples at three different elevations will be obtained from each tank sampled 
The hydrogen samples will be taken at tank bottom (approximately 6" above liquid/sludge), at mid-tank and at the top of the tank. One volatile/semi-volatile organic compound sample will be collected by pumping 100 liters of the tank air through an activated charcoal cartridge, then a silica gel cartridge using a Constant Flow Air Sampler. This sample will be taken at mid-tank elevation. The Tedlar ${ }^{\circledast}$ bags, activated charcoal cartridges, and silica gel cartridges will be sent to ADS and analyzed for the constituents shown in Table 1.

\subsection{Analytical Methodologies}

The analytical procedures that will be used by ADS are listed in Table 2, corresponding to the list of the constituents and physical parameters shown in Table 1.

Appendix A lists the applicable ADS procedure titles from the Savannah River Technology Center ADS Analytical Operating Procedures, Manual L16.1.

\section{FIELD DOCUMENTATION RECORDS}

\subsection{Field Sample Chain-of-Custody}

Samples will be assigned unique numbers in the field that identify the specific tank and sample type for each sample.

A formal quality control process (COC) will be used to ensure the integrity of the samples from the point of origin through the sample analysis is implemented. This process will demonstrate that the samples obtained in the field have been securely transported, and have reached the analytical laboratory without alteration. The COC process has been established by SRS Environmental Compliance procedures. An example COC form is shown in Figure 5. The COC within the ADS laboratories will be maintained in accordance with SRTC-ADS COC procedure?

\subsection{Holding Times, Sample Packaging, and Shipment}

The time required for shipping samples to the laboratory will be minimized to the extent possible. Sample holding times shall be commensurate with EPA Guidelines ${ }^{8}$. The shortest holding time for the samples that will be collected is 14 days for volatiles in aqueous samples. ADS will be responsible for ensuring that samples are analyzed within EPA specified holding times, as shown in Table 2. Samples will be packaged for shipment in accordance WSRC Transportation Procedures (Radioactive Material Packaging Certification and Authorization Requirements). Samples will be transported in accordance with WSRC Transportation Procedures (Radioactive Materials Transported In Excepted Packages). The WSRC Transportation Procedure demonstrates compliance with Department of Energy transportation safety standards. 


\subsection{Investigation Derived Waste (IDW)}

Pending the results of laboratory analysis, the aqueous and non-aqueous IDW will be handled in accordance with SRS Management Plan (WSRC-RP-91227) Rev. $2^{9}$. The laboratory results will be compared to the limits set in the Management Plan to determine the final disposition of the wastes.

\section{QUALITY ASSURANCE PROJECT PLAN (QAPJP)}

WSRC Procedure Quality Assurance Plan (QAP) $21-1^{10}$ establishes quality assurance requirements and responsibilities for environmental data collection and evaluation activities. This Sampling and Analysis Plan (SAP) is designed to comply with QAP 21-1 guidelines. The elements for a Quality Assurance Project Plan (QAPjP) called for under this SRS site guidance are addressed below. If the element has been previously addressed elsewhere in this document the appropriate section is referenced.

\subsection{Project Description}

A brief description of the project and its objectives is provided in Section 1.

\subsection{Project Organization and Responsibility}

The Analytical Development Section (ADS) of the Savannah River Technology Center (SRTC) will be the point of contact and will have overall responsibility for implementation of this SAP.

Environmental Restoration is responsible for the field collection of the samples.

ADS will provide technical assistance as required, and will ensure that adequately qualified personnel and necessary equipment are available to complete the laboratory work in a timely manner.

ADS will be responsible for the technical review of the data, results, and Quality Control (QC) information obtained throughout the project.

\subsection{Data Quality Objectives}

Data Quality Objectives are described in Section 3.

\subsection{Sample Collection, Control, and Transport}

Sampling methodologies are provided in Section 4. Sampling details and radiological controls will be specified in the Solvent Tank Specific Sampling Procedure and Radiation Work Permit. 


\subsection{Analytical Procedures}

The applicable standard operating procedure for each measurement parameter is provided in Appendix A. ADS results would be Level 5 results, per WSRC Manual 1Q, Procedure 21-1.

\subsection{Calibration Procedures}

Calibration procedural steps are described within the applicable standard operating procedure for each measurement parameter as provided in Table 2 .

\subsection{Waste Disposal}

The handling and disposal of waste materials resulting from field investigations is presented in Section 5.3. Waste resulting from laboratory operations will be in accordance with ADS procedures.

\subsection{Internal Quality Control Checks}

ADS has in place a Quality Assurance Program Plan that provides internal quality control checks on analytical work.

\subsection{Performance Assessments}

SRTC has in place a Quality Assurance internal assessment program that provides independent review. Non-compliance issues will be logged, documented, and controlled through assessment findings, which are attached to and become a part of the internal assessment report. These assessment findings will be directed to the appropriate supervisor for corrective action in a specified and timely manner.

\subsection{Preventative Maintenance}

Preventative maintenance procedural steps are described within the applicable standard operating procedure for each measurement parameter as provided in Table 2. Service to all equipment, instruments, tools, gauges, etc., will be performed only by qualified personnel. Non-conforming items will be managed in accordance with the Program Plan.

\subsection{Corrective Action}

When a significant condition adverse to quality is noted, the cause of the condition will be determined and corrective action will be taken to preclude repetition of the same condition. Condition identification and cause, documents affected, and corrective action will be documented and reported to ADS. Implementation of corrective action will be verified by documented follow-up action. All task personnel have the responsibility, as part of the normal work duties, to promptly identify and report conditions adverse to quality. Non-conforming items or services will be documented on an Nonconformance Report Form. 


\subsection{Reports to Management}

Field logbooks will be maintained for recording and reporting field activity. Analytical results will be compiled within ADS, including the QA status of measurement systems and data.

\section{REFERENCES}

1. Procedure WAC 3.16, Solvent Storage Tank Facility - Waste Acceptance Criteria, Rev. 0, WSRC Manual 1S, Savannah River Site, Aiken, SC 29808 (1997).

2. Procedure WAC 3.17, Low Level Radioactive Waste Acceptance Criteria, Rev. 1, WSRC Manual 1S, Savannah River Site, Aiken, SC 29808 (1997).

3. Brown, D. F. and Georgeton, G.K. Waste Acceptance Criteria for High Level Liquid Waste Transfers to the 241-F/H Tank Farms (U), X-SD-G-00001, Rev. 1, Savannah River Site, Aiken, SC 29808 (1995).

4. Procedure WAC 3.07, Mixed Waste Storage Facilities - Mixed Waste Acceptance Criteria, Rev. 3, WSRC Manual 1S, Savannah River Site, Aiken, SC 29808 (1997).

5. Procedure WAC 3.06, E-Area, TRU Pads Transuranic Waste Acceptance Criteria, Rev. 3, WSRC Manual 1S, Savannah River Site, Aiken, SC 29808 (1995).

6. Procedure 21.1, Sample Chain-of-Custody, Rev. 0, WSRC Manual 3Q, Savannah River Site, Aiken, SC 29808 (1995).

7. Procedure ADS-1006, Rev. 1, Chain-of-Custody, Savannah River Technology Center ADS Analytical Operating Procedures, Manual L16.1, Westinghouse Savannah River Company, Savannah River Site, Aiken, SC 29808 (1996).

8. USEPA, SW-846 Test Methods for Evaluating Solid Waste Physical/Chemical Methods, U. S. Environmental Protection Agency, Office of Solid Waste and the National Technical Information Service (NTIS), Springfield, VA 22161 (1996)

9. SRS, IDW Management Plan, WSRC-RP-91227, Rev. 2, Westinghouse Savannah River Company, Aiken, SC 29808 (1994).

10. Procedure 21-1, Quality Assurance Requirements for the Collection and Evaluation of Environmental Data, Rev. 0, WSRC Manual 1Q, Savannah River Site, Aiken, SC 29808 (1994).

11. Franson, M. A., Ed. Standard Methods for the Examination of Waste and Wastewater, 17th ed., pg. 2-71, American Public Health Association, Washington, DC (1989) 
Savannah River Site

Sampling and Analysis Plan for Old Solvent Tanks S1-S22

to Address Waste Acceptance Criteria (U)
WSRC-RP-97-00770

Revision 0

October 2, 1997

Page 11 of 30

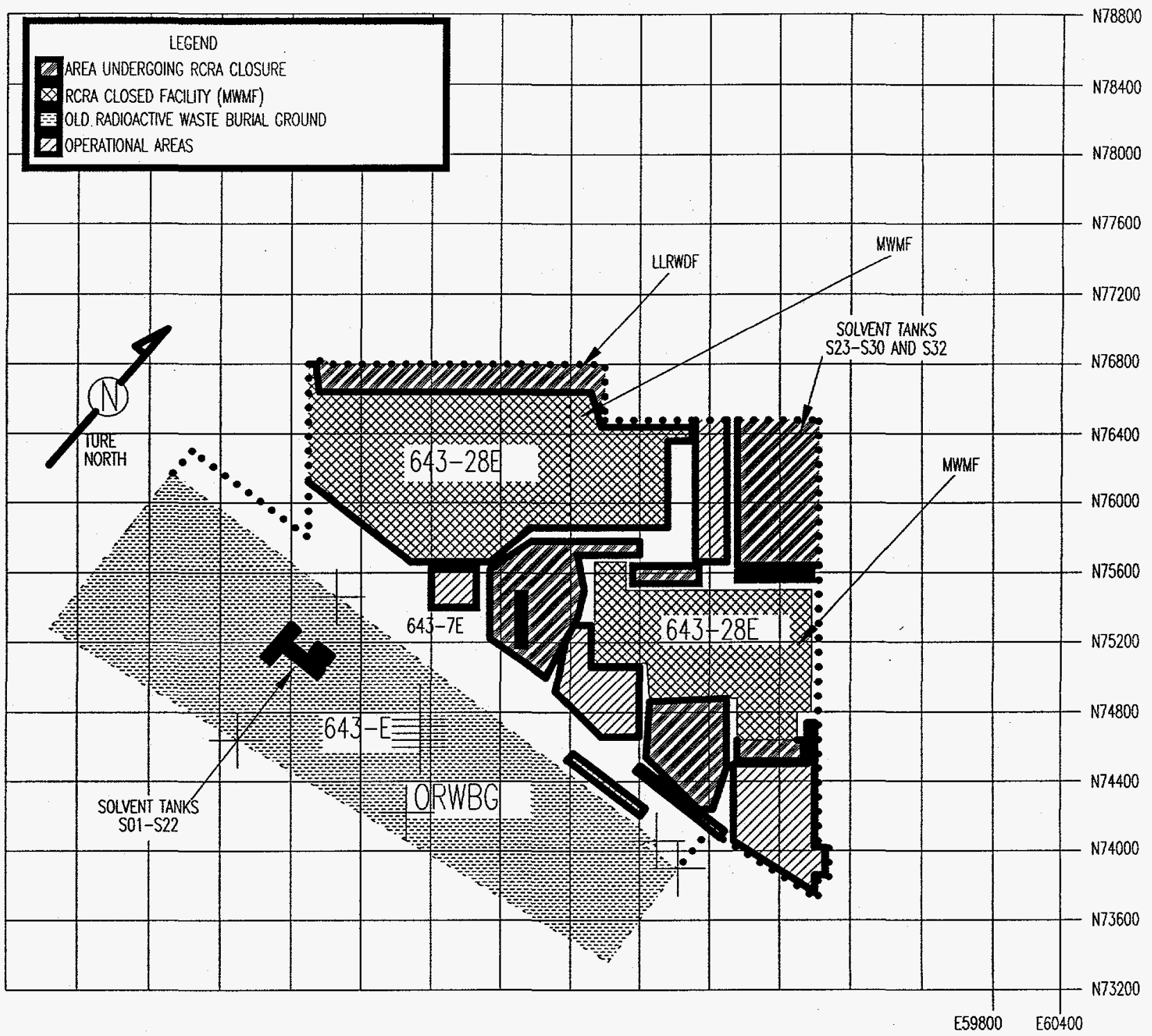

Figure 1. Location of the ORWBG in relation to other E Areas. 


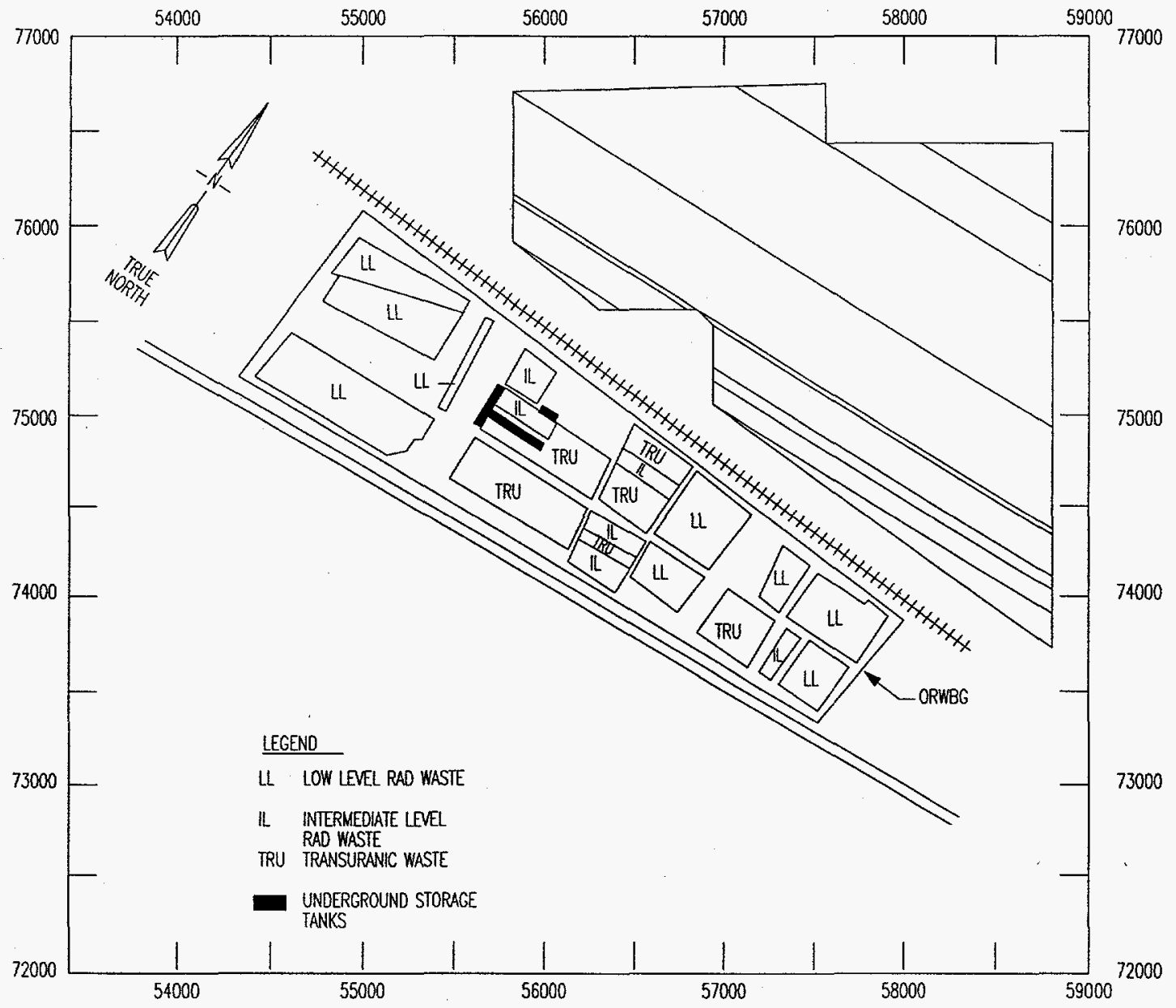

Figure 2. Location of Tanks S1-22 in Relation to the ORWBG 


\section{OLD SOLVENT TANK 643-E LAYOUT}

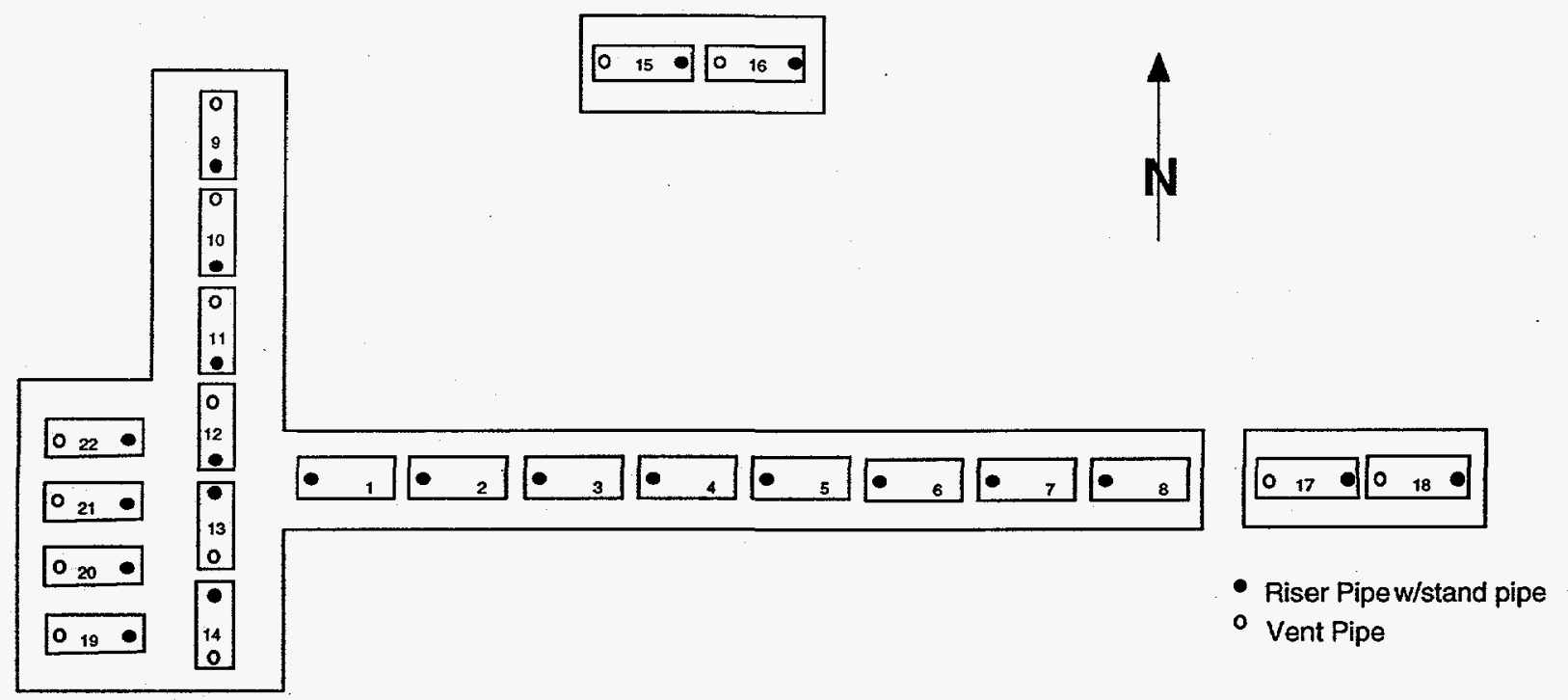

Figure 3. Relative locations of Tanks S1-22. 


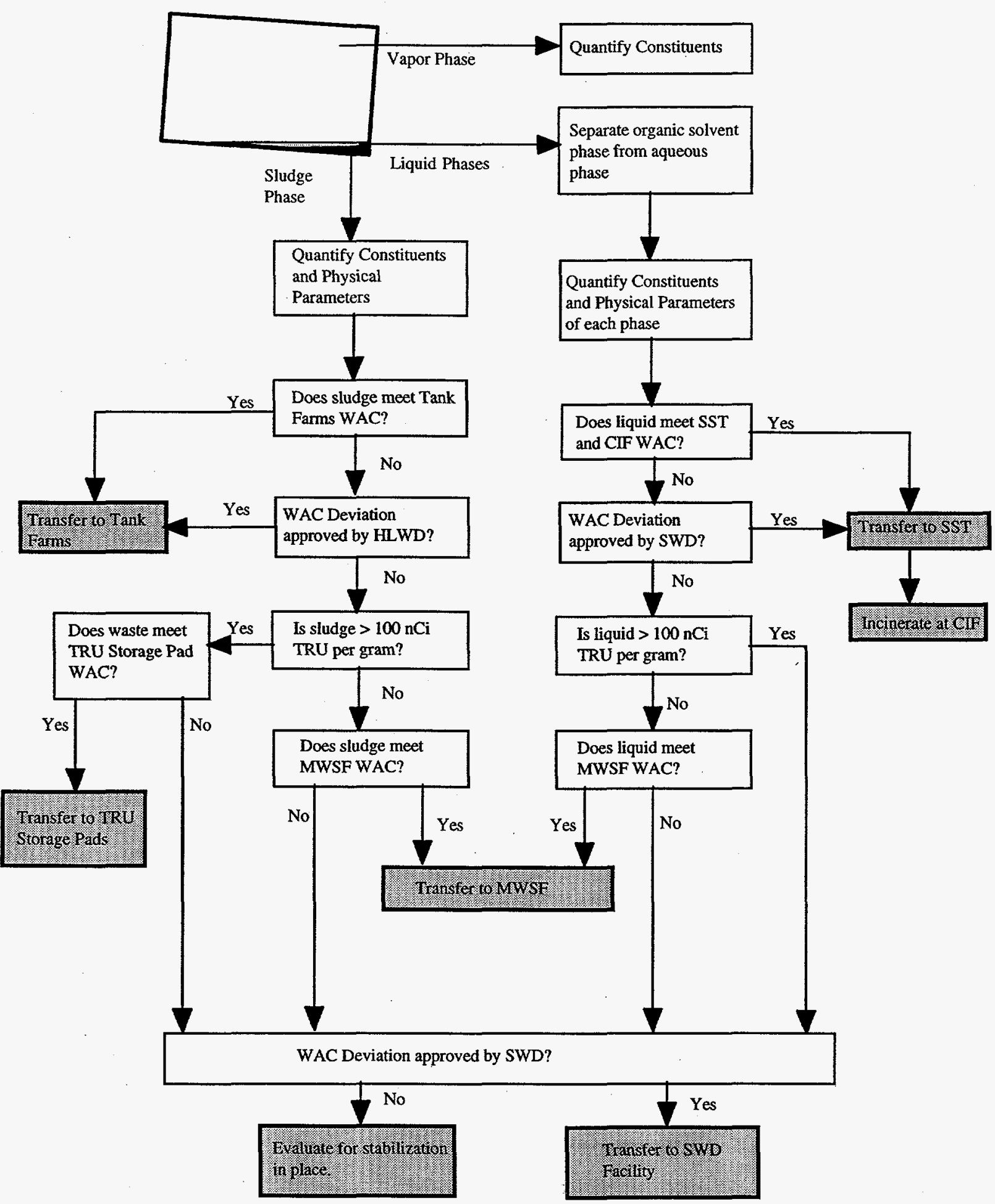

Figure 4. Material Disposition Strategy 


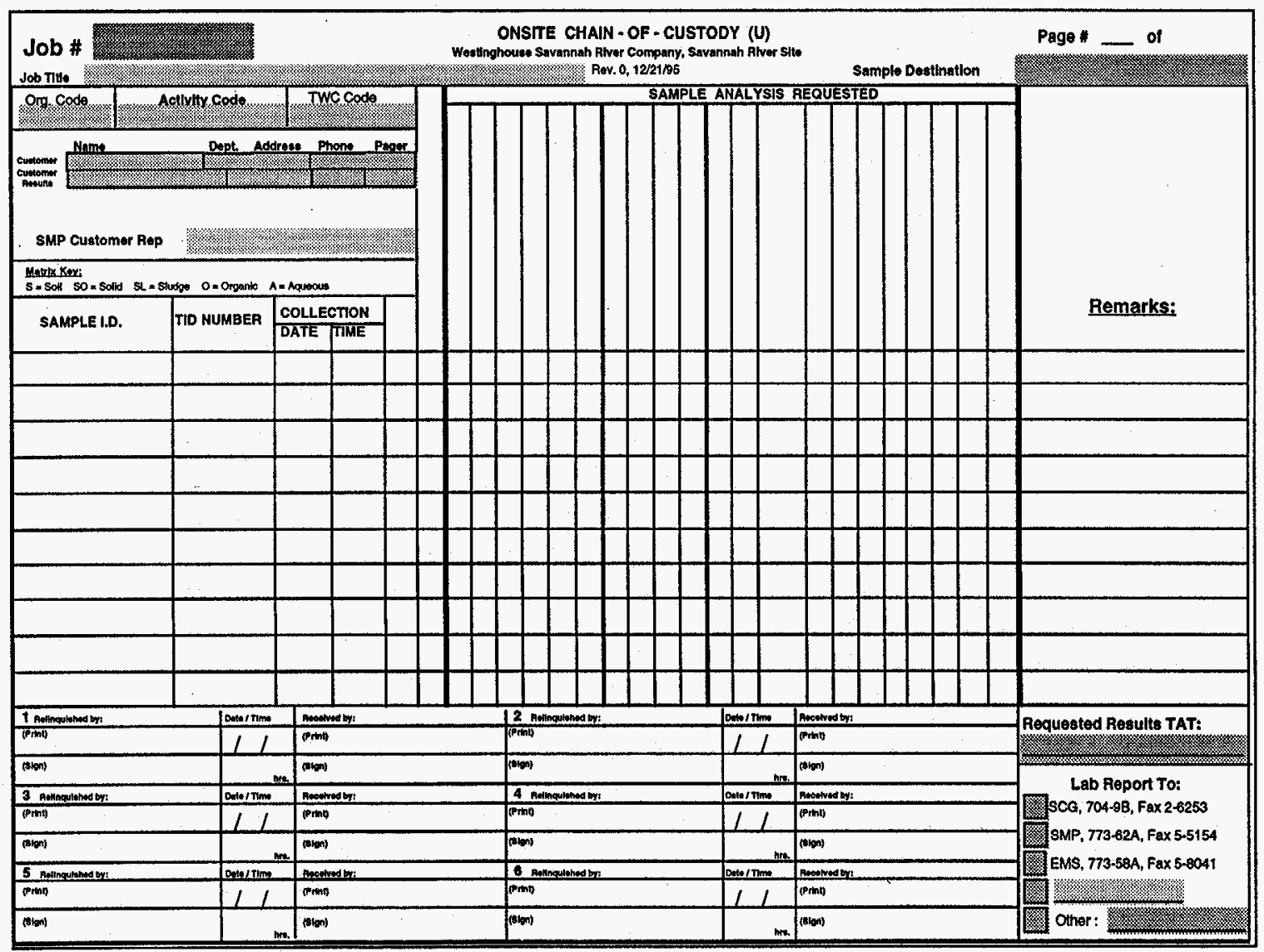

Figure 5 Field Chain-of-Custody Form 


\section{Table 1. Analytical Constituents, Parameters, and Detection Limits}

\begin{tabular}{|c|c|c|c|c|c|c|c|c|}
\hline \multicolumn{2}{|c|}{ Constituent/Parameter } & \multirow[t]{2}{*}{\begin{tabular}{|l|} 
WAC $(\mathrm{s})$ \\
F/H Tank Farms \\
\end{tabular}} & \multirow[t]{2}{*}{\begin{tabular}{|l} 
Vapor \\
\\
\end{tabular}} & \multirow[t]{2}{*}{\begin{tabular}{|l|} 
Organic \\
Liquid \\
\\
\end{tabular}} & \multirow[t]{2}{*}{\begin{tabular}{|l|} 
Aqueous \\
Liquid \\
\\
\end{tabular}} & \multirow[t]{2}{*}{\begin{tabular}{|l} 
Solid(s) \\
$X$ \\
\end{tabular}} & \multirow[t]{2}{*}{$\begin{array}{l}\text { Required Analytical } \\
\text { Detection Limit (Note 1) }\end{array}$} & \multirow[t]{2}{*}{$\begin{array}{l}\text { Typical } \\
\text { Analytical } \\
\text { Detection Limit } \\
\text { (Note } 2)\end{array}$} \\
\hline Aluminate & $\mathrm{AlO} 2-$ & & & & & & & \\
\hline \multirow[t]{3}{*}{ Aluminum } & \multirow[t]{3}{*}{ Al } & SST, CIF & & $\mathrm{X}$ & & & & $42 \mathrm{mg} / \mathrm{L}$ \\
\hline & & SST, CIF & & & $\mathrm{X}$ & & & $0.083 \mathrm{mg} / \mathrm{L}$ \\
\hline & & F/H Tank Farms & & & & $\mathrm{X}$ & & $830 \mathrm{mg} / \mathrm{Kg}$ \\
\hline Ammonium & $\mathrm{NH} 4+$ & F/H Tank Farms & & & & $\mathrm{X}$ & $\leq 0.56 \mathrm{wt} \%$ in solution & \\
\hline \multirow[t]{3}{*}{ Antimony } & \multirow[t]{3}{*}{$\mathrm{Sb}$} & SST, CIF & & $\mathrm{X}$ & & & $730 \mathrm{mg} / \mathrm{Kg}$ & $100 \mathrm{mg} / \mathrm{L}$ \\
\hline & & SST, CIF & & & $\mathrm{X}$ & & $730 \mathrm{mg} / \mathrm{Kg}$ & $0.2 \mathrm{mg} / \mathrm{L}$ \\
\hline & & F/H Tank Farms & & & & $\mathrm{X}$ & & $2000 \mathrm{mg} / \mathrm{Kg}$ \\
\hline \multirow[t]{3}{*}{ Arsenic } & \multirow[t]{3}{*}{ As } & SST, CIF & & $\mathrm{X}$ & & & $50 \mathrm{mg} / \mathrm{Kg}$ & $3 \mathrm{mg} / \mathrm{L}$ \\
\hline & & SST, CIF & & & $\mathrm{X}$ & & $50 \mathrm{mg} / \mathrm{Kg}$ & $0.005 \mathrm{mg} / \mathrm{L}$ \\
\hline & & F/H Tank Farms & & & & $\mathrm{X}$ & & $50 \mathrm{mg} / \mathrm{Kg}$ \\
\hline \multirow[t]{3}{*}{ Barium } & \multirow[t]{3}{*}{$\mathrm{Ba}$} & SST, CIF & & $\mathrm{X}$ & & & $\begin{array}{l}100,000 \mathrm{mg} / \mathrm{Kg}(\mathrm{CIF}) \\
\leq 1000 \mathrm{mg} / \mathrm{Kg}(\mathrm{SST})\end{array}$ & $2 \mathrm{mg} / \mathrm{L}$ \\
\hline & & SST, CIF & & & $\mathrm{X}$ & & $\begin{array}{l}100,000 \mathrm{mg} / \mathrm{Kg}(\mathrm{CIF}) \\
\leq 1000 \mathrm{mg} / \mathrm{Kg}(\mathrm{SST})\end{array}$ & $0.004 \mathrm{mg} / \mathrm{L}$ \\
\hline & & $\mathrm{F} / \mathrm{H}$ Tank Farms & & & & $\mathrm{X}$ & & $40 \mathrm{mg} / \mathrm{Kg}$ \\
\hline \multirow[t]{3}{*}{ Beryllium } & \multirow[t]{3}{*}{$\mathrm{Be}$} & SST, CIF & & $\mathrm{X}$ & & & Detectable & $2 \mathrm{mg} / \mathrm{L}$ \\
\hline & & SST, CIF & & & $\mathrm{X}$ & & Detectable & $0.004 \mathrm{mg} / \mathrm{L}$ \\
\hline & & $\mathrm{F} / \mathrm{H}$ Tank Farms & & & & $\mathrm{X}$ & & $40 \mathrm{mg} / \mathrm{Kg}$ \\
\hline \multirow[t]{3}{*}{ Boron } & \multirow[t]{3}{*}{$\mathrm{B}$} & SST, CIF & & $\mathrm{X}$ & & & & $10 \mathrm{mg} / \mathrm{L}$ \\
\hline & & SST, CIF & & & $\mathrm{X}$ & & & $0.02 \mathrm{mg} / \mathrm{L}$ \\
\hline & & $\mathrm{F} / \mathrm{H}$ Tank Farms & & & & $\mathrm{X}$ & & $200 \mathrm{mg} / \mathrm{Kg}$ \\
\hline \multirow[t]{3}{*}{ Cadmium } & \multirow[t]{3}{*}{$\mathrm{Cd}$} & SST, CIF & & $\mathrm{X}$ & & & $20 \mathrm{mg} / \mathrm{Kg}$ & $1 \mathrm{mg} / \mathrm{L}$ \\
\hline & & SST, CIF & & & $\mathrm{X}$ & & $20 \mathrm{mg} / \mathrm{Kg}$ & $0.002 \mathrm{mg} / \mathrm{L}$ \\
\hline & & $\mathrm{F} / \mathrm{H}$ Tank Farms & & & & $\mathrm{X}$ & $20 \mathrm{mg} / \mathrm{Kg}$ (Note 3) & $19 \mathrm{mg} / \mathrm{Kg}$ \\
\hline
\end{tabular}


Table 1. (cont.)

\begin{tabular}{|c|c|c|c|c|c|c|c|c|}
\hline \multicolumn{2}{|c|}{ Constituent/Parameter } & WAC(s) & Vapor & $\begin{array}{l}\text { Organic } \\
\text { Liquid }\end{array}$ & $\begin{array}{l}\text { Aqueous } \\
\text { Liquid }\end{array}$ & Solid(s) & $\begin{array}{l}\text { Required Analytical } \\
\text { Detection Limit (Note 1) }\end{array}$ & $\begin{array}{l}\text { Typical } \\
\text { Analytical } \\
\text { Detection Limit } \\
\text { (Note 2) } \\
\end{array}$ \\
\hline Carbonate & CO3- & F/H Tank Farms & & & & $X$ & & \\
\hline \multirow[t]{3}{*}{ Chloride } & \multirow[t]{3}{*}{$\mathrm{Cl}-$} & SST, CIF & & Note 4 & & & & \\
\hline & & SST, CIF & & & $\mathrm{X}$ & & & $0.2 \mathrm{mg} / \mathrm{L}$ \\
\hline & & F/H Tank Farms & & & & $\mathrm{X}$ & $\leq 0.11 \mathrm{M} \simeq 3.8 \mathrm{~g} / \mathrm{L}$ & \\
\hline \multirow[t]{3}{*}{ Chromium } & \multirow[t]{3}{*}{$\mathrm{Cr}$} & SST, CIF & & $\mathrm{X}$ & & & $2500 \mathrm{mg} / \mathrm{Kg}$ & $3 \mathrm{mg} / \mathrm{L}$ \\
\hline & & SST, CIF & & & $\mathrm{X}$ & & $2500 \mathrm{mg} / \mathrm{Kg}$ & $0.006 \mathrm{mg} / \mathrm{L}$ \\
\hline & & F/H Tank Farms & & & & $\mathrm{X}$ & & $63 \mathrm{mg} / \mathrm{Kg}$ \\
\hline \multirow[t]{3}{*}{ Copper } & \multirow[t]{3}{*}{$\mathrm{Cu}$} & SST, CIF & & $\mathrm{X}$ & & & & $4 \mathrm{mg} / \mathrm{L}$ \\
\hline & & SST, CIF & & & $\mathrm{X}$ & & & $0.009 \mathrm{mg} / \mathrm{L}$ \\
\hline & & F/H Tank Farms & & & & $\mathrm{X}$ & & $87 \mathrm{mg} / \mathrm{Kg}$ \\
\hline \multirow[t]{2}{*}{ Cyanide } & \multirow[t]{2}{*}{$\mathrm{CN}-$} & SST, CIF, MWSF & & & $\mathrm{X}$ & & & \\
\hline & & Tank Farms, MWSF & & & & $\mathrm{X}$ & & \\
\hline Fluoride & F- & F/H Tank Farms & & & & $\mathrm{X}$ & $\leq 0.086 \mathrm{M} \simeq 1600 \mathrm{mg} / \mathrm{L}$ & $0.2 \mathrm{mg} / \mathrm{L}$ \\
\hline $\begin{array}{l}\text { Hydroxide, } \\
\text { Free }\end{array}$ & $\mathrm{OH}-$ & F/H Tank Farms & & & & $\mathrm{X}$ & & \\
\hline \multirow[t]{3}{*}{ Iron } & \multirow[t]{3}{*}{$\mathrm{Fe}$} & SST, CIF & & $\mathrm{X}$ & & & & $3 \mathrm{mg} / \mathrm{L}$ \\
\hline & & SST, CIF & & & $\mathrm{X}$ & & & $0.006 \mathrm{mg} / \mathrm{L}$ \\
\hline & & F/H Tank Farms & & & & $\mathrm{X}$ & & $64 \mathrm{mg} / \mathrm{Kg}$ \\
\hline \multirow[t]{3}{*}{ Lead } & \multirow[t]{3}{*}{$\mathrm{Pb}$} & SST, CIF & & $\mathrm{X}$ & & & $10,000 \mathrm{mg} / \mathrm{Kg}$ & $26 \mathrm{mg} / \mathrm{L}$ \\
\hline & & SST, CIF & & & $\mathrm{X}$ & & $10,000 \mathrm{mg} / \mathrm{Kg}$ & $0.052 \mathrm{mg} / \mathrm{L}$ \\
\hline & & F/H Tank Farms & & & & $\mathrm{X}$ & & $520 \mathrm{mg} / \mathrm{Kg}$ \\
\hline \multirow[t]{3}{*}{ Manganese } & \multirow[t]{3}{*}{$\mathrm{Mn}$} & SST, CIF & & $\mathrm{X}$ & & & & $1 \mathrm{mg} / \mathrm{L}$ \\
\hline & & SST, CIF & & & $\mathrm{X}$ & & & $0.001 \mathrm{mg} / \mathrm{L}$ \\
\hline & & Criticality & & & & $\mathrm{X}$ & & $13 \mathrm{mg} / \mathrm{Kg}$ \\
\hline
\end{tabular}


Table 1. (cont.)

\begin{tabular}{|c|c|c|c|c|c|c|c|c|}
\hline \multicolumn{2}{|c|}{ Constituent/Parámeter } & WAC(s) & Vapor & $\begin{array}{l}\text { Organic } \\
\text { Liquid }\end{array}$ & $\begin{array}{l}\text { Aqueous } \\
\text { Liquid }\end{array}$ & Solid(s) & $\begin{array}{l}\text { Required Analytical } \\
\text { Detection Limit (Note 1) }\end{array}$ & $\begin{array}{l}\text { Typical } \\
\text { Analytical } \\
\text { Detection Limit } \\
\text { (Note 2) }\end{array}$ \\
\hline \multirow[t]{3}{*}{ Mercury } & \multirow[t]{3}{*}{$\mathrm{Hg}$} & SST, CIF & & $\mathrm{X}$ & & & $260 \mathrm{mg} / \mathrm{Kg}$ & $100 \mathrm{mg} / \mathrm{L}$ \\
\hline & & SST, CIF & & & $\mathrm{X}$ & & $260 \mathrm{mg} / \mathrm{Kg}$ & $0.2 \mathrm{mg} / \mathrm{L}$ \\
\hline & & F/H Tank Farms & & & & $\mathrm{X}$ & & $2000 \mathrm{mg} / \mathrm{Kg}$ \\
\hline \multirow[t]{3}{*}{ Nickel } & \multirow[t]{3}{*}{$\mathrm{Ni}$} & SST, CIF & & $\mathrm{X}$ & & & $600 \mathrm{mg} / \mathrm{L}$ & $5 \mathrm{mg} / \mathrm{L}$ \\
\hline & & SST, CIF & & & $\mathrm{X}$ & & $600 \mathrm{mg} / \mathrm{L}$ & $0.01 \mathrm{mg} / \mathrm{L}$ \\
\hline & & Criticality & & & & $X$ & & $96 \mathrm{mg} / \mathrm{Kg}$ \\
\hline \multirow[t]{2}{*}{ Nitrate } & \multirow[t]{2}{*}{ NO3- } & SST, CIF & & & $\mathrm{X}$ & & & $1 \mathrm{mg} / \mathrm{L}$ \\
\hline & & F/H Tank Farms & & & & $\mathrm{X}$ & $\begin{array}{l}\leq 8.5 \mathrm{M} \simeq 535,000 \mathrm{mg} / \mathrm{L} \\
\text { Dependent on } \mathrm{OH}-\text { and } \\
\mathrm{NO} 2-\text { concentration. }\end{array}$ & \\
\hline Nitrite & NO2- & $\mathrm{F} / \mathrm{H}$ Tank Farms & & & & $\mathrm{X}$ & $\begin{array}{l}\text { Dependent on OH- and } \\
\text { NO3-concentration. }\end{array}$ & $1 \mathrm{mg} / \mathrm{L}$ \\
\hline Oxalate & $\mathrm{C} 2 \mathrm{O} 4-$ & F/H Tank Farms & & & & $\mathrm{X}$ & & $1 \mathrm{mg} / \mathrm{L}$ \\
\hline \multirow[t]{2}{*}{ Phosphate } & \multirow[t]{2}{*}{ (PO4) -3 } & SST, CIF & & & $\mathrm{X}$ & & & $1 \mathrm{mg} / \mathrm{L}$ \\
\hline & & $\mathrm{F} / \mathrm{H}$ Tank Farms & & & & $\mathrm{X}$ & & \\
\hline Potassium & $\mathrm{K}$ & F/H Tank Farms & & & & $\mathrm{X}$ & & $400 \mathrm{mg} / \mathrm{Kg}$ \\
\hline \multirow[t]{3}{*}{ Selenium } & \multirow[t]{3}{*}{$\mathrm{Se}$} & SST, CIF & & $\mathrm{X}$ & & & $0.1 \mathrm{mg} / \mathrm{L}$ & $3 \mathrm{mg} / \mathrm{L}$ \\
\hline & & SST, CIF & & & $\mathrm{X}$ & & $0.1 \mathrm{mg} / \mathrm{L}$ & $0.005 \mathrm{mg} / \mathrm{L}$ \\
\hline & & F/H Tank Farms & & & & $\mathrm{X}$ & & $50 \mathrm{mg} / \mathrm{Kg}$ \\
\hline \multirow[t]{3}{*}{ Silver } & \multirow[t]{3}{*}{$\mathrm{Ag}$} & SST, CIF & & $\mathrm{X}$ & & & $7,300 \mathrm{mg} / \mathrm{Kg}$ & $28 \mathrm{mg} / \mathrm{L}$ \\
\hline & & SST, CIF & & & $\mathrm{X}$ & & $7,300 \mathrm{mg} / \mathrm{Kg}$ & $0.055 \mathrm{mg} / \mathrm{L}$ \\
\hline & & F/H Tank Farms & & & & $\mathrm{X}$ & None detectable & $550 \mathrm{mg} / \mathrm{Kg}$ \\
\hline Sodium & $\mathrm{Na}$ & F/H Tank Farms & & & & $\mathrm{X}$ & & $700 \mathrm{mg} / \mathrm{Kg}$ \\
\hline Sulfate & (SO4) -2 & F/H Tank Farms & & & & $\mathrm{X}$ & $\leq 0.18 \mathrm{M} \simeq 17,000 \mathrm{mg} / \mathrm{L}$ & $0.5 \mathrm{ppm}$ \\
\hline \multirow[t]{2}{*}{ Thallium } & \multirow[t]{2}{*}{$\mathrm{Tl}$} & SST, CIF & & $\mathrm{X}$ & & & $730 \mathrm{mg} / \mathrm{Kg}$ & $30 \mathrm{mg} / \mathrm{L}$ \\
\hline & & SST, CIF & & & $\mathrm{X}$ & & $730 \mathrm{mg} / \mathrm{Kg}$ & $0.06 \mathrm{mg} / \mathrm{L}$ \\
\hline
\end{tabular}


Table 1. (cont.)

\begin{tabular}{|c|c|c|c|c|c|c|c|c|}
\hline \multicolumn{2}{|c|}{ Constituent/Parameter } & WAC(s) & Vapor & $\begin{array}{l}\text { Organic } \\
\text { Liquid }\end{array}$ & $\begin{array}{l}\text { Aqueous } \\
\text { Liquid }\end{array}$ & Solid(s) & $\begin{array}{l}\text { Required Analytical } \\
\text { Detection Limit (Note 1) }\end{array}$ & $\begin{array}{l}\text { Typical } \\
\text { Analytical } \\
\text { Detection Limit } \\
\text { (Note 2) } \\
\end{array}$ \\
\hline Titanium & $\mathrm{Ti}$ & F/H Tank Farms & & & & $\mathrm{X}$ & & $50 \mathrm{mg} / \mathrm{Kg}$ \\
\hline \multirow[t]{2}{*}{ Uranium } & \multirow[t]{2}{*}{$\mathrm{U}$} & SST, CIF & & $\mathrm{X}$ & & & & $18 \mathrm{mg} / \mathrm{L}$ \\
\hline & & SST, CIF & & & $\mathrm{X}$ & & & $0.036 \mathrm{mg} / \mathrm{L}$ \\
\hline \multirow[t]{3}{*}{ Zinc } & \multirow[t]{3}{*}{$\mathrm{Zn}$} & SST, CIF & & $\mathrm{X}$ & & & & $1 \mathrm{mg} / \mathrm{L}$ \\
\hline & & SST, CIF & & & $\mathrm{X}$ & & & $0.002 \mathrm{mg} / \mathrm{L}$ \\
\hline & & Criticality & & & & $\mathrm{X}$ & & $16 \mathrm{mg} / \mathrm{Kg}$ \\
\hline \multicolumn{2}{|c|}{ Crystallography } & $\begin{array}{l}\text { None, to support grout } \\
\text { formulation }\end{array}$ & & & & $\mathrm{X}$ & & \\
\hline \multicolumn{2}{|l|}{ TCLP } & $\begin{array}{l}\text { None, to support grout } \\
\text { formulation }\end{array}$ & & & & $\mathrm{X}$ & & \\
\hline \multicolumn{2}{|c|}{ Gas Constituents } & $\begin{array}{l}\text { None, for environmental, } \\
\text { safety and health. }\end{array}$ & $\mathrm{X}$ & & & & & \\
\hline \multicolumn{2}{|c|}{$\begin{array}{l}\text { Any known volatiles > } \\
20 \mathrm{mg} / \mathrm{L}\end{array}$} & F/H Tank Farms & & & & Note 5 & & \\
\hline \multicolumn{2}{|c|}{ n-Butanol } & F/H Tank Farms & & & & & & \\
\hline \multicolumn{2}{|c|}{$\begin{array}{l}\text { Phenol/phenoxide/nitrop } \\
\text { henols }\end{array}$} & \multicolumn{2}{|l|}{ SST, CIF, F/H Tank Farms } & Note 6 & Note 6 & Note 6 & & \\
\hline \multicolumn{2}{|c|}{ Semi-Volatile Organics } & SST, CIF & $\mathrm{X}$ & Note 7 & Note 7 & & & \\
\hline \multicolumn{2}{|c|}{ Total Organic Carbon } & \multicolumn{2}{|l|}{ SST, CIF, F/H Tank Farms } & $\mathrm{X}$ & $\mathrm{X}$ & $\mathrm{X}$ & & \\
\hline \multicolumn{2}{|c|}{ Volatile \% Organics } & F/H Tank Farms & & & & $\mathrm{X}$ & $<0.5 \mathrm{vol} \%$ & \\
\hline \multicolumn{2}{|c|}{ Volatile Organics } & SST, CIF & Note 5 & Note 5 & Note 5 & & & \\
\hline \multicolumn{2}{|c|}{ PCBs } & SST, CIF, MWSF & & $\mathrm{X}$ & $\mathrm{X}$ & $\mathrm{X}$ & $<50 \mathrm{ppm}$ & \\
\hline \multicolumn{2}{|c|}{$\begin{array}{l}\text { Kepone, p- } \\
\text { Nitrophenol }\end{array}$} & SST, CIF & & Note 7 & Note 7 & & Detectable (SST) & \\
\hline
\end{tabular}


Table 1. (cont.)

\begin{tabular}{|c|c|c|c|c|c|c|c|}
\hline Constituent/Parameter & WAC(s) & Vapor & $\begin{array}{l}\text { Organic } \\
\text { Liquid }\end{array}$ & $\begin{array}{l}\text { Aqueous } \\
\text { Liquid }\end{array}$ & Solid(s) & $\begin{array}{l}\text { Required Analytical } \\
\text { Detection Limit (Note 1) }\end{array}$ & $\begin{array}{l}\text { Typical } \\
\text { Analytical } \\
\text { Detection Limit } \\
\text { (Note 2) }\end{array}$ \\
\hline Benzene & SST, CIF & & Note 5 & Note 5 & & & \\
\hline MEK, PCE & SST, CIF & & Note 5 & Note 5 & & & \\
\hline Acidity & SST, CIF & & & $\mathrm{X}$ & & & \\
\hline Boiling Point & SST, CIF & & $\mathrm{X}$ & $\mathrm{X}$ & & $\geq 135^{\circ} \mathrm{F}$ & \\
\hline BTU/lb & SST, CIF & & $\mathrm{X}$ & $\mathrm{X}$ & & $\geq 5000$ & \\
\hline Flash Point & SST, CIF & & $\mathrm{X}$ & $\mathrm{X}$ & & $\geq 140^{\circ} \mathrm{F}$ & \\
\hline Freezing Point & SST, CIF & & $\mathrm{X}$ & $\mathrm{X}$ & & $\leq 40^{\circ} \mathrm{F}$ & \\
\hline Paint Filter Liquids Test & SST, CIF & & $\mathrm{X}$ & $\mathrm{X}$ & & & \\
\hline \multirow[t]{2}{*}{$\mathrm{pH}$} & \multicolumn{2}{|l|}{ SST, CIF, MWSF } & & $\mathrm{X}$ & & $4 \leq \mathrm{pH} \leq 12.5$ & \\
\hline & \multicolumn{2}{|l|}{ F/H Tank Farms, MWSF } & & & $\mathrm{X}$ & $\mathrm{pH}>9.5$ & \\
\hline Specific Gravity & \multicolumn{2}{|l|}{ SST, CIF, F/H Tank Farms } & $\mathrm{X}$ & $\mathrm{X}$ & $\mathrm{X}$ & $\leq 1.15$ & \\
\hline Total Dissolved Solids & \multicolumn{2}{|l|}{$\begin{array}{l}\text { SST, CIF, F/H Tank Farms, } \\
\text { MWSF }\end{array}$} & $\mathrm{X}$ & $\mathrm{X}$ & $\mathrm{X}$ & & \\
\hline $\begin{array}{l}\text { Total } \\
\text { Insoluble/Suspended } \\
\text { Solids }\end{array}$ & \multicolumn{2}{|l|}{$\begin{array}{l}\text { SST, CIF, F/H Tank Farms, } \\
\text { MWSF }\end{array}$} & $\mathrm{X}$ & $\mathrm{X}$ & $\mathrm{X}$ & $\begin{array}{l}\leq 10 \mathrm{wt} \% \text { Total Suspended } \\
\text { Solids }\end{array}$ & \\
\hline Viscosity & SST, CIF & & $\mathrm{X}$ & $\mathrm{X}$ & & $0.002-0.045$ Pas @ 25ㄷ & \\
\hline Water, wt $\%$ & SST, CIF & & $\mathrm{X}$ & $\mathrm{X}$ & & & $0.002 \mathrm{wt} \%$ \\
\hline \multirow[t]{3}{*}{ Am-241 } & ES\&H & Note 8 & & & & None Specified & \\
\hline & SST, CIF, MWSF & & $\mathrm{X}$ & $\mathrm{X}$ & & $1.00 \mathrm{E}-05 \mu \mathrm{Ci} / \mathrm{cc}$ (Note 9) & $9 \mathrm{E}-6 \mu \mathrm{Ci} / \mathrm{mL}$ \\
\hline & MWSF & & & & $\mathrm{X}$ & $1.00 \mathrm{E}-05 \mu \mathrm{Ci} / \mathrm{g}$ (Note 9 ) & \\
\hline Am Series, Total & F/H Tank Farms & & & & Note 10 & & \\
\hline
\end{tabular}


Table 1. (cont.)

\begin{tabular}{|c|c|c|c|c|c|c|c|}
\hline Constituent/Parameter & WAC(s) & Vapor & $\begin{array}{l}\text { Organic } \\
\text { Liquid }\end{array}$ & \begin{tabular}{|l|} 
Aqueous \\
Liquid
\end{tabular} & Solid(s) & $\begin{array}{l}\text { Required Analytical } \\
\text { Detection Limit (Note 1) }\end{array}$ & $\begin{array}{l}\text { Typical } \\
\text { Analytical } \\
\text { Detection Limit } \\
\text { (Note 2) } \\
\end{array}$ \\
\hline \multirow[t]{2}{*}{$\mathrm{C}-14$} & SST, CIF, MWSF & & $\mathrm{X}$ & $X$ & & $1.00 \mathrm{E}-05 \mu \mathrm{Ci} / \mathrm{cc}$ (Note 9) & $1 \mathrm{E}-5 \mu \mathrm{Ci} / \mathrm{mL}$ \\
\hline & F/H Tank Farms, MWSF & & & & $\mathrm{X}$ & 1.00E-05 $\mu \mathrm{Ci} / \mathrm{g}$ (Note 9$)$ & \\
\hline \multirow[t]{3}{*}{$\mathrm{Ce}-144$} & ES\&H & Note 8 & & & & None Specified & \\
\hline & SST, CIF, MWSF & & $\mathrm{X}$ & $x$ & & $\begin{array}{l}<1 \% \text { Total Activity (Note } \\
11 \text { ) }\end{array}$ & $1 \mathrm{E}-5 \mu \mathrm{Ci} / \mathrm{mL}$ \\
\hline & F/H Tank Farms, MWSF & & & & $\mathrm{X}$ & $\begin{array}{l}<1 \% \text { Total Activity (Note } \\
11 \text { ) }\end{array}$ & \\
\hline Cm Series & F/H Tank Farms & & & & Note 12 & & $1 \mathrm{E}-5 \mu \mathrm{Ci} / \mathrm{mL}$ \\
\hline \multirow[t]{3}{*}{ Co-60 } & $\mathrm{ES \& H}$ & Note 8 & & & & None Specified & \\
\hline & SST, CIF, MWSF & & $\mathrm{X}$ & $\mathrm{X}$ & & $1.00 \mathrm{E}-04 \mu \mathrm{Ci} / \mathrm{cc}($ Note 9$)$ & $3 \mathrm{E}-6 \mu \mathrm{Ci} / \mathrm{mL}$ \\
\hline & F/H Tank Farms, MWSF & & & & $\mathrm{X}$ & 1.00E-04 $\mu \mathrm{Ci} / \mathrm{g}$ (Note 9) & \\
\hline Cs-134 & F/H Tank Farms & & & & $\mathrm{X}$ & & $2 \mathrm{E}-6 \mu \mathrm{Ci} / \mathrm{mL}$ \\
\hline \multirow[t]{3}{*}{ Cs-137 } & ES\&H & Note 8 & & & & None Specified & \\
\hline & SST, CIF, MWSF & & $\mathrm{X}$ & $\mathrm{X}$ & & $1.00 \mathrm{E}-05 \mu \mathrm{Ci} / \mathrm{cc}($ Note 9) & $4 \mathrm{E}-6 \mu \mathrm{Ci} / \mathrm{mL}$ \\
\hline & F/H Tank Farms, MWSF & & & & $\mathrm{X}$ & $<3.48 \mathrm{E}+03 \mathrm{dpm} / \mathrm{ml}$ & \\
\hline Eu-154 & F/H Tank Farms & & & & $\mathrm{X}$ & & $3 \mathrm{E}-6 \mu \mathrm{Ci} / \mathrm{mL}$ \\
\hline \multirow[t]{3}{*}{ Gross Alpha } & ES\&H & $\mathrm{X}$ & & & & None Specified & \\
\hline & SST, CIF, MWSF & & $\mathrm{X}$ & $\mathrm{X}$ & & $5 \mathrm{nCi} / \mathrm{g}=5 \mathrm{E}-3 \mu \mathrm{Ci} / \mathrm{g}$ & $9 \mathrm{E}-6 \mu \mathrm{Ci} / \mathrm{mL}$ \\
\hline & F/H Tank Farms, MWSF & & & & $\mathrm{X}$ & & \\
\hline \multirow[t]{3}{*}{$\mathrm{H}-3$} & $\mathrm{ES \& H}$ & $\mathrm{X}$ & & & & None Specified & \\
\hline & SST, CIF, MWSF & & $\mathrm{X}$ & $\mathrm{X}$ & & $1.00 \mathrm{E}-04 \mu \mathrm{Ci} / \mathrm{cc}($ Note 9$)$ & $1 \mathrm{E}-4 \mu \mathrm{Ci} / \mathrm{mL}$ \\
\hline & F/H Tank Farms, MWSF & & & & $\mathrm{X}$ & 1.00E-04 $\mu \mathrm{Ci} / \mathrm{g}$ (Note 9) & \\
\hline
\end{tabular}


Table 1. (cont.)

\begin{tabular}{|c|c|c|c|c|c|c|c|}
\hline Constituent/Parameter & WAC(s) & Vapor & $\begin{array}{l}\text { Organic } \\
\text { Liquid }\end{array}$ & $\begin{array}{l}\text { Aqueous } \\
\text { Liquid }\end{array}$ & Solid(s) & $\begin{array}{l}\text { Required Analytical } \\
\text { Detection Limit (Note 1) }\end{array}$ & $\begin{array}{l}\text { Typical } \\
\text { Analytical } \\
\text { Detection Limit } \\
\text { (Note 2) }\end{array}$ \\
\hline \multirow[t]{2}{*}{$\mathrm{I}-129$} & SST, CIF, MWSF & & $\mathrm{X}$ & $\mathrm{X}$ & & $1.00 \mathrm{E}-06 \mu \mathrm{Ci} / \mathrm{cc}($ Note 9$)$ & $1 \mathrm{E}-6 \mu \mathrm{Ci} / \mathrm{mL}$ \\
\hline & F/H Tank Farms, MWSF & & & & $\mathrm{X}$ & $1.00 \mathrm{E}-06 \mu \mathrm{Ci} / \mathrm{g}$ (Note 9 ) & \\
\hline $\mathrm{Nb}-94$ & F/H Tank Farms & & & & $\mathrm{X}$ & & $3 \mathrm{E}-6 \mu \mathrm{Ci} / \mathrm{mL}$ \\
\hline \multirow[t]{2}{*}{$\mathrm{Ni}-59$} & SST, CIF, MWSF & & $\mathrm{X}$ & $\mathrm{X}$ & & $1.00 \mathrm{E}-04 \mu \mathrm{Ci} / \mathrm{cc}($ Note 9$)$ & $1 \mathrm{E}-4 \mu \mathrm{Ci} / \mathrm{mL}$ \\
\hline & F/H Tank Farms, MWSF & & & & $\mathrm{X}$ & $1.00 \mathrm{E}-04 \mu \mathrm{Ci} / \mathrm{g}$ (Note 9) & \\
\hline $\mathrm{Ni}-63$ & F/H Tank Farms & & & & $\mathrm{X}$ & & $1 \mathrm{E}-7 \mu \mathrm{Ci} / \mathrm{mL}$ \\
\hline \multirow[t]{3}{*}{ Gross Beta } & ES\&H & $\mathrm{X}$ & & & & None Specified & \\
\hline & SST, CIF, MWSF & & $\mathrm{X}$ & $\mathrm{X}$ & & $2600 \mathrm{nCi} / \mathrm{g}=2.6 \mu \mathrm{Ci} / \mathrm{g}$ & $9 \mathrm{E}-6 \mu \mathrm{Ci} / \mathrm{mL}$ \\
\hline & F/H Tank Farms, MWSF & & & & $\mathrm{X}$ & & \\
\hline \multirow[t]{3}{*}{$\mathrm{Np}-237$} & ES\&H & Note 8 & & & & None Specified & \\
\hline & SST, CIF, MWSF & & $\mathrm{X}$ & $\mathrm{X}$ & & $1.00 \mathrm{E}-06 \mu \mathrm{Ci} / \mathrm{cc}($ Note 9$)$ & $5 \mathrm{E}-6 \mu \mathrm{Ci} / \mathrm{mL}$ \\
\hline & F/H Tank Farms, MWSF & & & & $\mathrm{X}$ & $1.00 \mathrm{E}-06 \mu \mathrm{Ci} / \mathrm{g}$ (Note 9) & \\
\hline Plutonium, Total & F/H Tank Farms & & & & Note 13 & & \\
\hline \multirow[t]{2}{*}{ Plutonium-238 } & SST, CIF, MWSF & & $\mathrm{X}$ & $\mathrm{X}$ & & $1.00 \mathrm{E}-06 \mu \mathrm{Ci} / \mathrm{cc}($ Note 9$)$ & $1 \mathrm{E}-6 \mu \mathrm{Ci} / \mathrm{mL}$ \\
\hline & F/H Tank Farms, MWSF & & & & $\mathrm{X}$ & $1.00 \mathrm{E}-06 \mu \mathrm{Ci} / \mathrm{g}$ (Note 9$)$ & \\
\hline \multirow[t]{2}{*}{ Plutonium-239 } & SST, CIF, MWSF & & $\mathrm{X}$ & $\mathrm{X}$ & & $1.00 \mathrm{E}-06 \mu \mathrm{Ci} / \mathrm{cc}($ Note 9$)$ & $1 \mathrm{E}-6 \mu \mathrm{Ci} / \mathrm{mL}$ \\
\hline & F/H Tank Farms, MWSF & & & & $\mathrm{X}$ & $1.00 \mathrm{E}-06 \mu \mathrm{Ci} / \mathrm{g}$ (Note 9 ) & \\
\hline \multirow[t]{2}{*}{ Plutonium-240 } & SST, CIF, MWSF & & $\mathrm{X}$ & $\mathrm{X}$ & & $1.00 \mathrm{E}-06 \mu \mathrm{Ci} / \mathrm{cc}($ Note 9$)$ & $1 \mathrm{E}-6 \mu \mathrm{Ci} / \mathrm{mL}$ \\
\hline & F/H Tank Farms, MWSF & & & & $\mathrm{X}$ & 1.00E-06 $\mu \mathrm{Ci} / \mathrm{g}$ (Note 9) & \\
\hline \multirow[t]{2}{*}{ Plutonium-241 } & SST, CIF, MWSF & & $\mathrm{X}$ & $\mathrm{X}$ & & $\begin{array}{l}1.00 \mathrm{E}-05 \mu \mathrm{Ci} / \mathrm{cc} \text { or } \\
1 \% \text { Total Activity (Note } 14)\end{array}$ & $1 \mathrm{E}-6 \mu \mathrm{Ci} / \mathrm{mL}$ \\
\hline & F/H Tank Farms, MWSF & & & & $\mathrm{X}$ & $\begin{array}{l}1.00 \mathrm{E}-05 \mu \mathrm{Ci} / \mathrm{cc} \text { or } \\
1 \% \text { Total Activity (Note } 14)\end{array}$ & \\
\hline
\end{tabular}


Table 1. (cont.)

\begin{tabular}{|c|c|c|c|c|c|c|c|}
\hline Constituent/Parameter & WAC(s) & Vapor & $\begin{array}{l}\text { Organic } \\
\text { Liquid }\end{array}$ & $\begin{array}{l}\text { Aqueous } \\
\text { Liquid }\end{array}$ & Solid(s) & $\begin{array}{l}\text { Required Analytical } \\
\text { Detection Limit (Note 1) }\end{array}$ & \begin{tabular}{|l|} 
Typical \\
Analytical \\
Detection Limit \\
(Note 2) \\
\end{tabular} \\
\hline \multirow[t]{2}{*}{ Plutonium-242 } & SST, CIF, MWSF & & $\mathrm{X}$ & $\mathrm{X}$ & & $1.00 \mathrm{E}-06 \mu \mathrm{Ci} / \mathrm{cc}($ Note 9) & \\
\hline & F/H Tank Farms, MWSF & & & & $\mathrm{X}$ & $1.00 \mathrm{E}-06 \mu \mathrm{Ci} / \mathrm{g}$ (Note 9$)$ & \\
\hline \multirow[t]{3}{*}{$\mathrm{Pm}-147$} & ES\&H & Note 8 & & & & None Specified & \\
\hline & SST, CIF, MWSF & & $\mathrm{X}$ & $\mathrm{X}$ & & $\begin{array}{l}<1 \% \text { Total Activity (Note } \\
11 \text { ) }\end{array}$ & $1 \mathrm{E}-5 \mu \mathrm{Ci} / \mathrm{mL}$ \\
\hline & F/H Tank Farms, MWSF & & & & $\mathrm{X}$ & $\begin{array}{l}<1 \% \text { Total Activity (Note } \\
11 \text { ) }\end{array}$ & \\
\hline \multirow[t]{3}{*}{$\mathrm{Ru}-106$} & ES\&H & Note 8 & & & & None Specified & \\
\hline & SST, CIF, MWSF & & $\mathrm{X}$ & $\mathrm{X}$ & & $\begin{array}{l}<1 \% \text { Total Activity (Note } \\
11 \text { ) }\end{array}$ & $3 \mathrm{E}-5 \mu \mathrm{Ci} / \mathrm{mL}$ \\
\hline & F/H Tank Farms, MWSF & & & & $\mathrm{X}$ & $\begin{array}{l}<1 \% \text { Total Activity (Note } \\
11 \text { ) }\end{array}$ & \\
\hline $\mathrm{Sb}-125$ & F/H Tank Farms & & & & $\mathrm{X}$ & & $8 \mathrm{E}-6 \mu \mathrm{Ci} / \mathrm{mL}$ \\
\hline \multirow[t]{2}{*}{ Se-79 } & SST, CIF, MWSF & & $\mathrm{X}$ & $\mathrm{X}$ & & $\begin{array}{l}<1 \% \text { Total Activity (Note } \\
11 \text { ) }\end{array}$ & $1 \mathrm{E}-5 \mu \mathrm{Ci} / \mathrm{mL}$ \\
\hline & F/H Tank Farms, MWSF & & & & $\mathrm{x}$ & $\begin{array}{l}<1 \% \text { Total Activity (Note } \\
11 \text { ) }\end{array}$ & \\
\hline \multirow[t]{2}{*}{$S n-126$} & SST, CIF, MWSF & & $\mathrm{X}$ & $\mathrm{X}$ & & $\begin{array}{l}<1 \% \text { Total Activity (Note } \\
11 \text { ) }\end{array}$ & $2 \mathrm{E}-6 \mu \mathrm{Ci} / \mathrm{mL}$ \\
\hline & F/H Tank Farms, MWSF & & & & $\mathrm{X}$ & $\begin{array}{l}<1 \% \text { Total Activity (Note } \\
11 \text { ) }\end{array}$ & \\
\hline Sr-89 & F/H Tank Farms & & & & Note 15 & & \\
\hline \multirow[t]{2}{*}{ Sr-90 } & SST, CIF, MWSF & & $\mathrm{X}$ & $\mathrm{X}$ & & $1.00 \mathrm{E}-04 \mu \mathrm{Ci} / \mathrm{cc}($ Note 9$)$ & $1 \mathrm{E}-5 \mu \mathrm{Ci} / \mathrm{mL}$ \\
\hline & F/H Tank Farms, MWSF & & & & $\mathrm{X}$ & 1.00E-04 $\mu \mathrm{Ci} / \mathrm{g}$ (Note 9) & \\
\hline
\end{tabular}


Table 1. (cont.)

\begin{tabular}{|c|c|c|c|c|c|c|c|}
\hline Constituent/Parameter & WAC(s) & Vapor & $\begin{array}{l}\text { Organic } \\
\text { Liquid }\end{array}$ & $\begin{array}{l}\text { Aqueous } \\
\text { Liquid }\end{array}$ & Solid(s) & $\begin{array}{l}\text { Required Analytical } \\
\text { Detection Limit (Note 1) }\end{array}$ & $\begin{array}{l}\text { Typical } \\
\text { Analytical } \\
\text { Detection Limit } \\
\text { (Note 2) }\end{array}$ \\
\hline \multirow[t]{2}{*}{ Tc-99 } & SST, CIF, MWSF & & $\mathrm{X}$ & $\mathrm{X}$ & & 1.00E-06 $\mu \mathrm{Ci} / \mathrm{cc}$ (Note 9) & $1 \mathrm{E}-6 \mu \mathrm{Ci} / \mathrm{mL}$ \\
\hline & F/H Tank Farms, MWSF & & & & $\mathrm{X}$ & 1.00E-06 $\mu \mathrm{Ci} / \mathrm{g}$ (Note 9) & \\
\hline \multirow[t]{2}{*}{ Uranium-233 } & SST, CIF, MWSF & & $\mathrm{X}$ & $X$ & & $\begin{array}{l}1.00 \mathrm{E}-06 \mu \mathrm{Ci} / \mathrm{cc} \text { or } \\
1 \% \text { Total Activity (Note } 14)\end{array}$ & $1 \mathrm{E}-6 \mu \mathrm{Ci} / \mathrm{mL}$ \\
\hline & F/H Tank Farms, MWSF & & & & $\mathrm{X}$ & $\begin{array}{l}1.00 \mathrm{E}-06 \mu \mathrm{Ci} / \mathrm{cc} \text { or } \\
1 \% \text { Total Activity (Note } 14)\end{array}$ & \\
\hline \multirow[t]{2}{*}{ Uranium-234 } & SST, CIF, MWSF & & $\mathrm{X}$ & $\mathrm{X}$ & & 1.00E-06 $\mu \mathrm{Ci} / \mathrm{cc}($ Note 9$)$ & $1 \mathrm{E}-6 \mu \mathrm{Ci} / \mathrm{mL}$ \\
\hline & $\mathrm{F} / \mathrm{H}$ Tank Farms, MWSF & & & & $\mathrm{X}$ & 1.00E-06 $\mu \mathrm{Ci} / \mathrm{g}$ (Note 9) & \\
\hline \multirow[t]{2}{*}{ Uranium-235 } & SST, CIF, MWSF & & $\mathrm{X}$ & $X$ & & $\begin{array}{l}1.00 \mathrm{E}-06 \mathrm{uCi} / \mathrm{cc} \text { or } \\
1 \% \text { Total Activity (Note } 14)\end{array}$ & $1 \mathrm{E}-6 \mu \mathrm{Ci} / \mathrm{mL}$ \\
\hline & $\mathrm{F} / \mathrm{H}$ Tank Farms, MWSF & & & & $\mathrm{X}$ & $\begin{array}{l}1.00 \mathrm{E}-06 \mathrm{uCi} / \mathrm{cc} \text { or } \\
1 \% \text { Total Activity (Note } 14 \text { ) }\end{array}$ & \\
\hline \multirow[t]{2}{*}{ Uranium-236 } & SST, CIF, MWSF & & $\mathrm{X}$ & $\mathrm{X}$ & & $\begin{array}{l}1.00 \mathrm{E}-06 \mu \mathrm{Ci} / \mathrm{cc} \text { or } \\
1 \% \text { Total Activity (Note } 14)\end{array}$ & $1 \mathrm{E}-6 \mu \mathrm{Ci} / \mathrm{mL}$ \\
\hline & F/H Tank Farms, MWSF & & & & $\mathrm{X}$ & $\begin{array}{l}\text { 1.00E-06 } \mu \mathrm{Ci} / \mathrm{cc} \text { or } \\
1 \% \text { Total Activity }(\text { Note } 14)\end{array}$ & \\
\hline \multirow[t]{2}{*}{ Uranium-238 } & SST, CIF, MWSF & & $X$ & $\mathrm{X}$ & & $\begin{array}{l}\text { 1.00E-06 } \mu \mathrm{Ci} / \mathrm{cc} \text { or } \\
1 \% \text { Total Activity (Note } 14)\end{array}$ & $1 \mathrm{E}-6 \mu \mathrm{Ci} / \mathrm{mL}$ \\
\hline & F/H Tank Farms, MWSF & & & & $\mathrm{X}$ & $\begin{array}{l}\text { 1.00E-06 } \mu \mathrm{Ci} / \mathrm{cc} \text { or } \\
1 \% \text { Total Activity (Note } 14)\end{array}$ & \\
\hline
\end{tabular}

Table 1 Notes:

1. Required detection limits are from the respective WACs. 
2. Typical detection limits are listed for informational purposes, the actual detection limits obtained are sample-specific and may be higher or lower than those shown. The typical detection limits for the elemental analyses of the organic liquid assumed a $1 \mathrm{ml}$ sample digested and diluted to $50 \mathrm{~mL}$, with a 10-fold dilution prior to the spectroscopic measurement. The typical detection limits for the elemental analyses of the solid assumed a $0.25 \mathrm{~g}$ sample digested and diluted to $250 \mathrm{~mL}$, with a 10 -fold dilution prior to the spectroscopic measurement.

3. The required detection limit for these RCRA metals in the solid sample is assumed to be 20 times the leachate limit from the TCLP. The planned analyses will be total metal digestions, not leachings, these values account for the 20 -fold excess used in the TCLP.

4. Chlorine in the organic phase will be determined by summing the chlorinated hydrocarbons identified in the VOC and SVOC analyses.

5. The Volatile Organic Compound analysis addresses these specific WAC requirements: benzene, methyl ethyl ketone, perchloroethylene, n-butanol, any known volatiles $>20$ $\mathrm{mg} / \mathrm{L}$. It does not address methanol.

6. The addition of nitric acid to alkaline wastes may create nitrated organic compounds that did not originate in the sample.

7. The Semi-Volatile Organic Compound analysis addresses these specific WAC requirements: kepone and $\mathrm{p}$-nitrophenol.

8. Gamma spectroscopy of the vapor phase cartridges will identify Cs-137 and other gamma emitting radionuclides in the vapor phase.

9. WAC 2.02 in the WSRC 1S Manual requires documentation of the technical justification for exceeding these Maximum Allowable Lower Limit of Detection values.

10. Total americium will be the sum of any identified Am-241 and Am-243.

11. WAC 2.02 in the WSRC $1 S$ Manual defines a significance level of $1 \mathrm{Ci} \%$ for nuclides that do not have specific limits in WAC 3.17.

12. Total curium will be the sum of $\mathrm{Cm}-244$ and any other $\mathrm{Cm}$ isotopes identified by alpha spectrometry.

13. Total plutonium will be the sum of all identified $\mathrm{Pu}$ isotopes.

14. The required detection limit is assumed to be the greater of $1 \mathrm{Ci} \%$ or the Maximum Allowable Lower Limit of Detection value.

15. $\mathrm{Sr}-89$ will not be analyzed for due to the short half-life (50.5 days) and the age of the material in the tanks. 
Table 2. Analytical Methods and Hold Times

\begin{tabular}{|c|c|c|c|c|}
\hline Constituent/Parameter & & Technique & L16.1 Procedure & $\begin{array}{l}\text { Hold Time (per SW- } \\
846^{8} \text { ) }\end{array}$ \\
\hline $\begin{array}{l}\text { Aluminate, Carbonate, } \\
\text { and Free Hydroxide }\end{array}$ & $\mathrm{AlO}_{2}^{-}, \mathrm{CO}_{3}^{-}, \mathrm{OH}^{-}$ & Titration & ADS-2312 & \\
\hline $\begin{array}{l}\text { Aluminum, Antimony, } \\
\text { Barium, Beryllium, } \\
\text { Boron, Cadmium, } \\
\text { Chromium, Copper, } \\
\text { Iron, Lead, Manganese, } \\
\text { Nickel, Silver, Sodium, } \\
\text { Thallium, Titanium, } \\
\text { Uranium, Zinc } \\
\end{array}$ & $\begin{array}{l}\mathrm{Al}, \mathrm{Sb}, \mathrm{Ba}, \mathrm{Be} \\
\mathrm{B}, \mathrm{Cd}, \mathrm{Cr}, \mathrm{Cu} \\
\mathrm{Fe}, \mathrm{Pb}, \mathrm{Mn}, \mathrm{Ni} \\
\mathrm{Ag}, \mathrm{Na}, \mathrm{Tl}, \mathrm{Ti} \\
\mathrm{U}, \mathrm{Zn}\end{array}$ & ICP-ES & ADS-1509 & 6 months \\
\hline $\begin{array}{l}\text { Ammonium, Chloride, } \\
\text { Fluoride, Nitrate, } \\
\text { Nitrite, Oxalate, } \\
\text { Phosphate, Sulfate }\end{array}$ & $\begin{array}{l}\mathrm{NH}_{4}^{+}, \mathrm{Cl}^{-}, \mathrm{F} \\
\mathrm{NO}_{3}^{-}, \mathrm{NO}_{2}^{-} \\
\mathrm{C}_{2} \mathrm{O}_{4}^{-},\left(\mathrm{PO}_{4}\right)^{-3} \\
\left(\mathrm{SO}_{4}\right)^{-2}\end{array}$ & $\mathrm{IC}$ & ADS-2306 & $\begin{array}{l}\text { Not specified in SW- } \\
846\end{array}$ \\
\hline Cyanide & $\mathrm{CN}$ & & ADS-2278 & \\
\hline Arsenic, Selenium & As, Se & Hydride AAS & ADS-1557 & 6 months \\
\hline Mercury & $\mathrm{Hg}$ & CVAA & ADS-1556 & 28 days \\
\hline Potassium & $\mathrm{K}$ & Flame AAS & ADS-1549 & 6 months \\
\hline Crystallography & & XRD & ADS-1101 & \\
\hline TCLP & & Modified TCLP & ADS-2512 & \\
\hline Gas Constituents & & $\mathrm{GC}, \mathrm{GC} / \mathrm{MS}$ & ADS-1600 & \\
\hline $\begin{array}{l}\text { Phenol/phenoxide/nitro } \\
\text { phenols }\end{array}$ & & HPLC & Task Technical Plan & $\begin{array}{l}\text { Extract within } 14 \\
\text { days, analyze within } \\
40 \text { days of extraction }\end{array}$ \\
\hline Semi-Volatile Organics & & GC/MS & ADS-2657 & $\begin{array}{l}\text { Extract within } 14 \\
\text { days, analyze within } \\
40 \text { days of extraction }\end{array}$ \\
\hline Total Organic Carbon & & TOC & ADS- 1200 & $\begin{array}{l}\text { Not specified in SW- } \\
846\end{array}$ \\
\hline Volatile \% Organics & & \begin{tabular}{|l|} 
Oil Content \\
Analyzer
\end{tabular} & ADS-2213 & $\begin{array}{l}\text { Not specified in SW- } \\
846\end{array}$ \\
\hline Volatile Organics & & GC/MS & ADS-2656 & 14 days \\
\hline PCBs & & $\mathrm{GC}, \mathrm{GC} / \mathrm{MS}$ & ADS-2659 & $\begin{array}{l}\text { Extract within } 14 \\
\text { days, analyze within } \\
40 \text { days of extraction }\end{array}$ \\
\hline Acidity & & Titration & ADS-2301 & \\
\hline Boiling Point & & & ADS-2280 & \\
\hline $\mathrm{BTU} / \mathrm{lb}$ & & & ADS-2277 & \\
\hline Flash Point & & & ADS-2250 & \\
\hline
\end{tabular}


Table 2 (cont.)

\begin{tabular}{|c|c|c|c|}
\hline Constituent/Parameter & Technique & L16.1 Procedure & $\begin{array}{l}\text { Hold Time (per SW- } \\
846^{8} \text { ) }\end{array}$ \\
\hline Freezing Point & & ADS-2279 & \\
\hline $\begin{array}{l}\text { Paint Filter Liquids } \\
\text { Test }\end{array}$ & & ADS-2275 & $\begin{array}{l}\text { Not specified in SW- } \\
846\end{array}$ \\
\hline $\mathrm{pH}$ & & ADS-2309 & $\begin{array}{l}\text { Not specified in SW- } \\
846\end{array}$ \\
\hline \multicolumn{4}{|l|}{ Specific Gravity } \\
\hline $\begin{array}{l}\text { Total Dissolved, } \\
\text { Insoluble/Suspended } \\
\text { Solids }\end{array}$ & & $\begin{array}{l}\text { Standard Method } \\
2540^{11}\end{array}$ & \\
\hline Viscosity & & ADS-2276 & \\
\hline Water, wt\% & Karl-Fischer & ADS-2210 & \\
\hline $\begin{array}{l}\text { Am-241, Ce-144, Co-60, Cs-134, Cs- } \\
137, \text { Eu-154, Nb-94, Np-237, Ru-106, } \\
\text { Sb-125, Sn-126 }\end{array}$ & Gamma PHA & ADS-2420 & \\
\hline Am Series, Total & $\begin{array}{l}\text { Gamma and } \\
\text { Alpha PHA }\end{array}$ & $\begin{array}{l}\text { ADS-2420, ADS- } \\
2402\end{array}$ & \\
\hline $\mathrm{C}-14$ & $\begin{array}{l}\text { Separation \& } \\
\text { LSC }\end{array}$ & & \\
\hline Cm Series & Alpha PHA & ADS-2402 & \\
\hline Gross Alpha & Gross Alpha & ADS-2405 & $\begin{array}{l}\text { Not specified in SW- } \\
846\end{array}$ \\
\hline $\mathrm{H}-3$ & $\begin{array}{l}\text { Distillation \& } \\
\text { LSC }\end{array}$ & ADS-2444 & \\
\hline $\mathrm{I}-129$ & $\begin{array}{l}\text { Separation \& } \\
\text { LEPS }\end{array}$ & & \\
\hline Ni-59 & $\begin{array}{l}\text { Separation \& } \\
\text { XRS }\end{array}$ & ADS-2452 & \\
\hline $\mathrm{Ni}-63$ & $\begin{array}{l}\text { Separation \& } \\
\text { LSC }\end{array}$ & ADS-2452 & \\
\hline Gross Beta & LSC & ADS-2424 & $\begin{array}{l}\text { Not specified in SW- } \\
846\end{array}$ \\
\hline Plutonium, Total & Summation & & \\
\hline $\begin{array}{l}\mathrm{Pu}-238, \mathrm{Pu}-239, \mathrm{Pu}-240, \mathrm{Pu}-242, \mathrm{U}-233 \\
\mathrm{U}-234, \mathrm{U}-236, \mathrm{U}-238\end{array}$ & $\begin{array}{l}\text { ICP-MS \& Alpha } \\
\text { PHA }\end{array}$ & $\begin{array}{l}\text { ADS-1551, ADS- } \\
2402\end{array}$ & \\
\hline Plutonium-241 & $\begin{array}{l}\text { Separation \& } \\
\text { LSC }\end{array}$ & & \\
\hline $\mathrm{Pm}-147$ & $\begin{array}{l}\text { Separation \& } \\
\text { LSC }\end{array}$ & & \\
\hline $\mathrm{Se}-79$ & $\begin{array}{l}\text { Separation \& } \\
\text { LSC }\end{array}$ & & \\
\hline
\end{tabular}


Table 2 (cont.)

\begin{tabular}{|l|l|l|l|}
\hline Constituent/Parameter & Technique & L16.1 Procedure & $\begin{array}{l}\text { Hold Time (per SW- } \\
\left.846^{8}\right)\end{array}$ \\
\hline Sr-90 & $\begin{array}{l}\text { Separation \& } \\
\text { LSC }\end{array}$ & ADS-2447 & \\
\hline Tc-99 & $\begin{array}{l}\text { Separation \& } \\
\text { LSC }\end{array}$ & ADS-2445 & \\
\hline Uranium-235 & $\begin{array}{l}\text { ICP-MS, Gamma } \\
\text { PHA, Alpha } \\
\text { PHA }\end{array}$ & $\begin{array}{l}\text { ADS-1551, ADS- } \\
2420, \text { ADS-2402 }\end{array}$ & \\
\hline
\end{tabular}




\section{APPENDIX A. LIST OF ANALYTICAL PROCEDURES}

\begin{tabular}{|c|c|c|c|}
\hline $\begin{array}{l}\text { L16.1 } \\
\text { Procedure }\end{array}$ & Revision & Title & Year \\
\hline ADS-1101 & Rec. 3 & Siemens D-500 Contained X-Ray Diffreaction System (U) & 1995 \\
\hline ADS-1509 & Rev. 3 & $\begin{array}{l}\text { Inductively Coupled Plasma Emission Spectrometer for Aqueous } \\
\text { Liquid Sample Analysis ARL } 3580 \text { (U) }\end{array}$ & 1996 \\
\hline ADS-1549 & Rev. 1 & $\begin{array}{l}\text { Procedure for Operating Varian SpectrAA-400 Atomic Absorption } \\
\text { Spectrophotometer }(U)\end{array}$ & 1997 \\
\hline ADS-1551 & Rev. 0 & $\begin{array}{l}\text { Inductively Coupled Plasma-Mass Spectrometry Elemental and } \\
\text { Isotopic Analysis for Aqueous Liquid Sample Fisons Plasmaquad I (U) }\end{array}$ & 1996 \\
\hline ADS-1556 & Rev. 0 & $\begin{array}{l}\text { Procedure for Cold Vapor Atomic Absorption Determination of } \\
\text { Mercury on the Varian SpectrAA-400 Atomic Absorption } \\
\text { Spectrophotometer (U) }\end{array}$ & 1996 \\
\hline ADS-1557 & Rev. 0 & Procedure for Hydride Generation/Atomic Absorption (U) & 1997 \\
\hline ADS-1600 & Rev. 4 & Procedure for Gas Chromatography (U) & 1996 \\
\hline ADS-2210 & Rev. 6 & Water Determination with the Karl Fischer Reagent (U) & 1997 \\
\hline ADS-2213 & Rev. 4 & Measurement of Oil and Grease in Aqueous Suspensions (U) & 1996 \\
\hline ADS-2250 & Rev. 2 & $\begin{array}{l}\text { Flashpoint Determination Using Petrolab Mini-Flash Flashpoint Tester } \\
\text { (U) }\end{array}$ & 1996 \\
\hline ADS-2275 & Rev. 0 & EPA SW-846 Method 9095 Paint Filter Liquids Test(U) & 1997 \\
\hline ADS-2276 & Rev. 0 & $\begin{array}{l}\text { Measurement of Viscosity using Glass Capillary Kinematic Opaque } \\
\text { Viscosmeter }\end{array}$ & 1997 \\
\hline ADS-2277 & Rev. 0 & Measurement of Heat of Combustion of Liquids by Bomb Calorimetry & 1997 \\
\hline ADS-2278 & Rev. 0 & Measurement of Cyanide Ion in Aqueous Solutions & 1997 \\
\hline ADS-2279 & Rev. 0 & Freezing Point Determeination of Liquids & 1997 \\
\hline ADS-2280 & Rev. 0 & Boiling Point Determeination of Liquids & 1997 \\
\hline ADS-2276 & Rev. 0 & $\begin{array}{l}\text { Measurement of Viscosity using Glass Capillary Kinematic Opaque } \\
\text { Viscosmeter }\end{array}$ & 1997 \\
\hline ADS-2301 & Rev. 5 & Determination of Total Acid by Autotitration (U) & 1996 \\
\hline ADS-2306 & Rev. 6 & Analysis of Solutions by Ion Chromatography (U) & 1997 \\
\hline ADS-2309 & Rev. 4 & $\mathrm{pH}$ Determination of Aqueous Liquids (U) & 1996 \\
\hline ADS-2312 & Rev. 5 & $\begin{array}{l}\text { Automatic Determination of Hydroxide, Aluminate and Carbonate in } \\
\text { Alkaline Solutions of Nuclear.Waste (U) }\end{array}$ & 1996 \\
\hline ADS-2401 & Rev. 2 & Beta Liquid Scintillation (U) & 1995 \\
\hline ADS-2402 & Rev. 2 & Alpha Pulse Height Analysis (U) & 1994 \\
\hline ADS-2405 & Rev. 2 & Alpha and Beta Plate Making Direct Mount and Count (U) & 1995 \\
\hline ADS-2420 & Rev. 3 & Gamma Sample Preparation and Analysis (g-PHA) (U) & 1997 \\
\hline $\mathrm{ADS}-2424$ & Rev. 4 & Gross Alpha/Beta Determination by Liquid Scintillation Counting (U) & 1996 \\
\hline ADS-2444 & Rev. 1 & Tritium in Environmental Samples - A Distillation Procedure & 1996 \\
\hline ADS-2445 & Rev. 1 & Technicium-99 Extraction and Chromatography & 1996 \\
\hline ADS-2447 & Rev. 1 & Strontium-90 in Environmental Samples & 1996 \\
\hline ADS-2452 & Rev. 0 & $\mathrm{Ni}-59,63$ in Environmental and High Activity Samples & 1997 \\
\hline
\end{tabular}




\section{Appendix A (cont.)}

\begin{tabular}{|l|l|l|c|}
\hline $\begin{array}{l}\text { L16.1 } \\
\text { Procedure }\end{array}$ & Revision & Title & Year \\
\hline ADS-2512 & Rev. 2 & Modified Toxic Characteristic Leaching Procedure & 1996 \\
\hline ADS-2655 & Rev. 2 & High Performance Liquid Chromatography Operating Procedure (U) & 1996 \\
\hline ADS-2656 & Rev. 1 & $\begin{array}{l}\text { Gas Chromatography/Mass Spectrometry for Volatile Organics: } \\
\text { Contract Laboratory Program Methods (U) }\end{array}$ & 1996 \\
\hline ADS-2657 & Rev. 1 & $\begin{array}{l}\text { Gas Chromatography/Mass Spectrometry for Semi-Volatile Organics: } \\
\text { Contract Laboratory Program Methods (U) }\end{array}$ & 1997 \\
\hline ADS-2659 & Rev. 0 & $\begin{array}{l}\text { Gas Chromatography and Gas Chromatography/Mass Spectrometry for } \\
\text { Polychlorinated Biphenyls Analysis: Contract Laboratory Program } \\
\text { Methods (U) }\end{array}$ & 1995 \\
\hline
\end{tabular}

